GR

450

. M30 

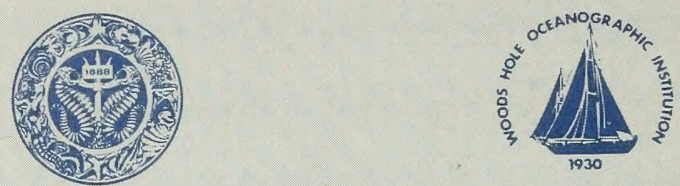

MBL/WHOI

LIBRARY

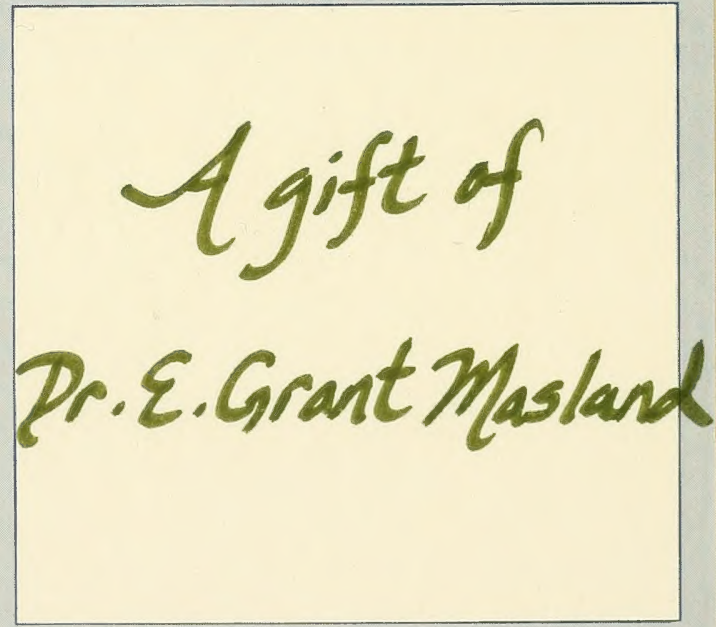


AS A TOKEN OF MY ADMIRATION FOR YOUR IRARE COMBINATION OF TOP SCHOLARS2IF IN SCIENCE WITH PRIME ABILITY AS A SPEAKER AND WRITER, AN OPWSCULUM MINUSCUZUM, WITH MY CORDIAL EEST WISMES. Walton Brooksmced aniel. 



\section{CONCEPTION, BIRTH AND INFANCY IN ANCIENT ROME AND MODERN ITALY}

WALTON BROOKS McDANIEL

Emeritus Professor of Latin

University of Pennsylvania
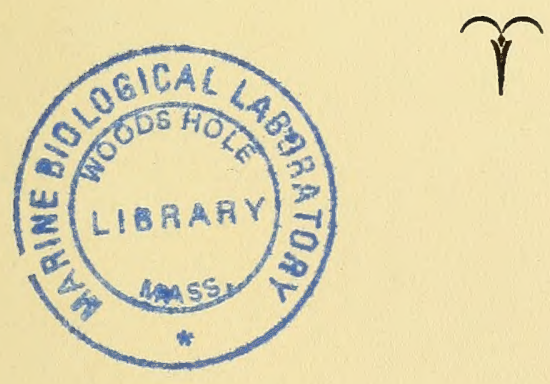

“SUNNYREST,” COCONUT GROVE

FLORIDA

1948 
Business Press, Inc.

Lancaster, Pennsyluania

Successor to

The Science Press Printing Co. 
PATRI ET MATRI 



\section{CONCEPTION, BIRTH AND INFANCY IN ANCIENT ROME AND MODERN ITALY}

There have been many scholars who have sought to learn all that they could from ancient art and literature about the Roman child. They have written articles and books that have dealt with such matters as conception and the methods which some used to prevent it, the pregnancy and parturition of the mother, and the period of infancy. On these topics no classical specialist can hope to add much that is new to what has been already published in one language or another. But there is a somewhat novel angle from which he can approach them. Very rarely, indeed, has any researcher or literary writer paid the slightest attention to the birth and early life of a modern Italian baby, Giulio or Giulia, for the purpose of instituting the interesting and sometimes, I believe, illuminating comparisons which can be made with the life of Julius and Julia, their remote ancestors. It is this comparative method that I have used in all my study of the ancient Romans, and now, as I am nearing, supposedly, the period of my own second childhood, I can see a certain appropriateness in turning my attention to matters that are concerned with the infancy of man.

Perhaps few of my readers have had occasion to consider how small a portion of Latin writing from the Republican and early Imperial periods of Roman history has actually survived. If we only had more of the letters that were interchanged, more of the orations that were delivered, more of the ordinary personal poetry that was composed, and, particularly, more of the public and private inscriptions that were cut, scratched, and painted, we might form rather different opinions of the people as a whole. It is quite possible that Father Time, however grudging we classicists may consider him to have been, has actually allowed to reach our age a generous representation of Rome's best literature, but we must remember that works that deserve praise from the point of view of literary art may yet be far from dependable sources to use too exclusively in judging an entire civilization. It has been unfortunate for the Romans that so many of her most widely read and most entertaining authors have belonged to a 
rather small upper class in the community, and have used their talent for social and ethical analysis and for satirical description and censure with but slight regard for the fairness and breadth of view that modern principles of historical criticism require. The specialist may point out that the dissolute conditions in Roman society which the poet Ovid has vividly depicted-himself a recognized master in the arts of seduction and, we suspect, an active and successful practitioner in that field-do not hold true for earlier ages, nor even for all ranks of society in his own day. A scholar may furthermore emphasize the fact that Roman satirists and moralists like Horace, Persius, Juvenal, Martial, and Seneca, often say in a piquant fashion and with an exaggeration which may be born of indignation but is too often largely a product of rhetoric, things which we must weigh with a scrupulous care. But the influence of the classical scholar and teacher cannot reach very far in an age which can scarcely keep up with its own modernity. The findings of dispassionate investigators of Roman family life have little effect upon those adepts in popular sensationalism, whether novelists, painters, play-wrights, or pulpiteers, who have been responsible for the ideas which the ordinary layman cherishes concerning Roman character and conduct. It is spectacular and sometimes salacious movies founded upon Quo Vadis, The Last Days of Pompeii and the like that provide the mental pictures of our contemporaries, and the less knowledge any informed spectator takes to them the less will be his irritation at their falsities both in spirit and in fact.

It is only too apparent that in all that concerns the sexual and family life of antiquity our purveyors of excitement have catered to the popular love of intrigue, scandal, and lubricity. In what I shall have to say about conception, pregnancy, birth, and babyhood among the Romans in correlation with information from modern Italian life, which is often curiously parallel, I am attempting to set forth thoughts and procedures of people living at two widely separate periods in Italian history which I think may interest the general reader as well as the student. If some of the facts, especially some in the field of folkmedicine with which this work will have much to do, seem incomprehensibly strange or even sensational, they will owe nothing of their quality to the writer's fancy or diction. I write soberly and must often present a rather 
depressing picture of humanity in even this century of Christian culture. Unequal treatment of topics will, of course, be inevitable because of disparities in the amount of data available for drawing our comparisons.

While research reveals an astonishing amount of parallelism between superstitious ideas and practices of the Romans and those found among Italians of recent times, we must always bear in mind that the latter are treasured for the most part by the less intelligent and least educated members of any community. Moreover, it is never safe to generalize from the instances that I have found and to conclude that the same superstition is current in all parts of the country, because it is reported from several widely separated regions. We simply lack the data, and until there are many more folklorists at work in Italy than there have yet been or are at all likely to be, we cannot have even a near approach to a comprehensive account. What chiefly interests us is to find any survivals at all of thoroughly pagan and irrational beliefs and practices after the lapse of so many centuries and in an age that has enjoyed the advantages of scientific scholarship and of the wide dissemination of its teaching. Let us begin with the baby's beginning, or to speak more accurately, with efforts to prevent his coming into being at all.

Although, for one reason or another, information about contraceptives and abortives excited interest among the Romans, as appears from the attention that Pliny the Elder gives them in his Historia Naturalis as well as from a few references in other authors, ${ }^{1}$ yet we cannot stress too strongly the fact that Romans married primarily in order to produce children who should perpetuate the family and perform the religious rites which were thought to be essential for the happiness of both the living and the dead, and who should fulfil civic and military duties in default of which the nation could not endure. Laws penalized even with exile those who committed abortion. ${ }^{2}$ Of course, for reasons that cannot be set forth here, there was plenty of licentious living at Rome, and increasingly so as the Republican period drew to a close, but during many centuries the family occupied a position of respect, and its purity enjoyed a rating of importance that Greek and much Oriental life of the time does not match. We think of this when we note how in Roman Catholic Italy the 
movement for birth control has won no such favor as it has in many other countries. Some of the reasons behind Papal opposition would appeal strongly to, let us say, Cato, the Censor, or any other high-placed Roman of early days.

Mussolini was a genuine old Roman in emphasizing the importance of large families to Church and State, as the Papacy and Fascism respectively conceive that church and state ought to be. ${ }^{3} \quad$ Furthermore, he was a patriot of a not wholly unreasoning optimism when he cherished the thought that the fatherland might yet, as a land of fathers, merely through a cunicular fecundity conquer much of the world for Rome-a military victory achieved through sound biological principles and practices, but one which, if we judge from present prospects, is a long, long way off!

In spite of this powerful opposition from both Church and Fascism, interest in ways of restricting the size of the family has been mounting in Italy, and information and misinformation about contraceptives and abortives circulate in the folkmedicine of the land. It is with these and not, of course, with any scientific methods of regular medicine that we are going to deal, since they are the ones which have ancient antecedents. ${ }^{4}$

Such Italian women as put their faith in popular precepts may use as safeguards decoctions made from the leaves or other parts of elder, willow, valerian, dittany, rue, swallowwort, maidenhair fern, and sage. Savin, a juniper (Juniperus sabina) is employed in local applications. Much of this lore has commanded belief for thousands of years. ${ }^{5}$ Thus, people have thought of ferns as plants that have no seeds and so as obviously possessed of power to make women sterile or to bring about an abortion. ${ }^{6}$ The fern figures prominently, it is needless to say, in the botany of witchcraft. $^{7}$ Other preventives and abortifacients in more or less vogue among rustics are the testicles of a hare dried and reduced to powder, the scrapings of a tobacco pipe, water which has remained in casks of anchovies. ${ }^{8}$ The first of these sounds more like a recipe to encourage fecundity, especially in view of the animal chosen for the sacrifice, but the second cannot be very ancient, although it is true that smoking other things than tobacco was known to Roman soldiers, and some of the pipes that were used resemble those that are familiar now. 
The region of Perugia offers folklore on our subject which is sufficiently absurd to match the superstitions of even the most primitive age. In order to escape pregnancy a woman must avoid the greeting or even the glance of a midwife and, during intercourse, hold a container of mercury on her chest or wear a bit of stag skin. Alternatives are to drink in wine scrapings from the hoof of a mule or some steel filings. ${ }^{9}$ The contribution of the mule is explicable,${ }^{9 a}$ the avoidance of a midwife is consonant with magic doctrine, but just how the metals are going to do their work I must leave to others to conjecture.

We wish that we possessed something comparable with modern detailed statistics on births and deaths for any ancient city, but we have but little information on which to build. Interest centered then on rare or sensational phenomena, such as prolonged or abbreviated gestation, ${ }^{10}$ Caesarotomy, ${ }^{11}$ the birth of monstrosities, ${ }^{12}$ mutation of sex, ${ }^{13}$ and multiparity. ${ }^{14}$ The cure of sterility and the use of aphrodisiacs and anaphrodisiacs much engaged the attention of medical men and, we need hardly add, of the immortal tribe of quacks and operators in magic. Why should any woman continue to grieve over her childlessness, when conception within three days was guaranteed her if she would eat in her food the eye of a hyaena along with some licorice and anise? ${ }^{15}$ Another insurance was to take in drink, they said, certain little worms to the number of five or seven. ${ }^{16}$ Pliny says that the dung of hawks taken in honied wine seems to make women fruitful. ${ }^{17}$ So, too, eating partridge eggs. ${ }^{18}$ Some agents that were recommended belong in the field of magic and are consequently utterly absurd. ${ }^{19}$

The excitants to venery and their opposites, the anaphrodisiacs, in which the Romans were asked to put their trust when they wished to arouse passion in a loved one or make it futile in some rival, range from those which are primarily pharmaceutical to those that may be termed purely magical. The drugs mentioned in literature would be, we know, in some cases powerless, except for their effect upon the mind, in others, likely to produce the opposite effect, and in still others, so dangerous to use that insanity or death, as ancient writers themselves recognize, could be the result. Since, however, the Roman husband and wife of our present account may be considered an ordinary healthy 
couple, we shall ignore the topic of philtres and love charms in this discussion.

The actual fecundity of married women in Italy in our time is sure to impress a tourist if he happens to come from a land and from a social class in which the family stock commonly produces but a single flower. In Italy one may see so many children gathered around still youngish parents that one wonders whether they may not have arrived not as singlets but in veritable clusters. To speak in the terminology of the old Romans, we seem to be viewing not a mere familia but an entire gens. Pitifully often the poor of the community appear to possess little else but a horde of children. It is probable that in ancient Rome babies came to the young mother in quick succession, and that in the ignorance of hygiene which characterized the age, infant mortality reached a high rate even in normal times when neither famine nor pestilence was afflicting the city. Insanitary conditions fostered any endemic disease, and malnutrition lowered the resistance of the young. We can assume, I believe, that ignorance of a proper diet, superstitious practices and medical quackery destined much of the annual increase in Roman families to a premature end.

While the diffusion of scientific knowledge in Italy has reduced in recent years the chance of finding the beliefs and practices of Roman times surviving there in the fields of procreation, obstetrics, and pediatrics, there are yet some legacies discoverable. For example, a classicist will learn with interest that a test of conception to which Catullus refers in a well-known passage of one of his poems is still employed. On the morning after the wedding the interested inquisitor encircles the woman's neck with a cord to see whether its measurement has increased since the day before: a greater circumference is a sign that she has conceived. ${ }^{20}$ It is curious that one of the ancient tests of virginity, the burning of jet, gargates, also served to determine whether a slave on sale was subject to epilepsy and so no bargain, and whether a person who had fallen to the ground was in an epileptic fit or was merely the victim of somebody's magic spell. In the thirteenth century the test to ascertain the condition of a woman was not the fumigation, but a drink of water in which the jet was immersed. It acted as an immediate diuretic, we are told, if she were a maiden. We suspect, however, that she had to be a believer in the criterion 
or, perhaps, to be thoroughly frightened by her submission to it if she was to prove responsive. ${ }^{21}$

There is a belief as old as Roman days that during a woman's period of gestation any special desires that she cherishes should, if possible, be gratified..$^{22}$ Since, according to this persistent superstition, the baby will bear a birthmark which pictures more or less perfectly the object of his mother's craving at whatever place on his body the woman may be touching on her own as she does her wishing, a foresighted Italian who senses that she has centered her desire overmuch on something touches her buttocks, and this, she imagines, will protect her child from having a disfigurement on some more public part of its anatomy. ${ }^{23}$ However, the situation at the worst is not hopeless: the marking of the newborn can be cancelled, it is claimed, by washing it with a little blood from the placenta upon which it depended as a fetus. ${ }^{24}$ The mother herself may have to suffer when she fails to get something that she "honed for" during pregnancy. Thus, an unsatisfied craving for an eel may bring upon her a facial neuralgia, a tic douloureux. ${ }^{25}$ It may seem to us a strange choice of food anyway where there were so many other possibilities for her fancy to dwell on. But, of course, it could be near Christmas Eve when the place of honor on the festal board goes to the capitone. It would be like denying a New Englander turkey at Thanksgiving time.

Roman parents who had set their hearts on having children were naturally anxious that a conception should not be in vain. They recognized many perils, many of them such as no gynecologist would think of today. For instance, we are warned that the stench of a lamp that has just been extinguished may be enough to cause an abortion. ${ }^{26}$ This may seem amusing when we recall how ignorant of sanitation and of chemical controls ancient communities were, so that malodor would be ubiquitous among the people and sudden affronts to the nose scarcely avoidable. We are told, furthermore, that miscarriage may occur, if the woman merely sneezes after sexual congress, or yawns at the time of her delivery, ${ }^{27}$ or even looks at a sea hare. ${ }^{28}$

The Romans were acquainted with Greek medical works on chaplets which told which flowers were injurious to the head. ${ }^{29}$ This was of interest to them, since wreaths and cut flowers were used in abundance at their banquets in spite of their tendency to 
wither disagreeably, dining-rooms could rarely boast of much ventilation, and lamps burning olive oil and provided with no chimneys would add odor as well as heat to apartments. Among modern peoples it is the Italian that seems to be most sensitive about having cut flowers in a room. ${ }^{30}$ Some Italians of the south believe that the scent poisons the blood and causes fever. ${ }^{31}$ An Italian woman who is about to bear a child is especially guarded against the odor of fresh flowers and artificial floral perfumes. ${ }^{32}$ They are likely, it is believed, to make her miscarry. Yet, curiously enough, a pregnant woman may be observed walking about in public with leaves of centaury, the matricaria, stuck in her nostrils in the belief that they act as a calmative and prevent spasms.

During the trying period of pregnancy it is natural enough for the more ignorant among Italian women to resort to adepts in quackery and superstitious practices who can still be found readily enough in backward communities. On the advice of some old crone, the local repository of traditional lore, they may act quite as an ancestress of theirs would have done two thousand years ago and employ for safety or for relief devices of a similar occult character. Roman remedies and magic ways to safeguard a pregnant woman against miscarriage are often mentioned, and some of them must have stirred the risibility of the more intelligent and better educated people of Rome as much as they do our own. We wonder, for instance, how many wives would actually wear suspended from their neck in a container made of antelope skin some white flesh from the breast of a hyaena, the genitals of a stag, and seven of its hairs, ${ }^{33}$ or would apply an ointment consisting of the ashes of burnt hedgehogs mixed with oil. ${ }^{34} \mathrm{~A}$ pregnant woman is especially cautioned against stepping over a raven's egg lest she miscarry by the mouth. To eat one causes the same result. Even having eggs of this bird under the same roof makes delivery difficult. Back of all this, is, of course, the vulgar belief that ravens couple or lay by means of the beak..$^{35}$

One of the most remarkable safeguards proposed for the period of pregnancy of which I know is the use of what the ancients called an eagle-stone. According to beliefs of which Pliny the Elder has preserved the record, certain eagles use in the construction of their aeries this aëtites or gangites. ${ }^{36}$ He speaks of it 
as incombustible, and as of having value only when taken from the nest of these birds. The stone has in it another one which can be heard to rattle when shaken. An imaginative Roman could think of it, therefore, as pregnant, as a sort of womb with a fetus inside, and we read, indeed, of several other stones of a similar nature which were said to have conceived and, in some cases, to carry their contents for a specific period of time. ${ }^{37} \mathrm{We}$ are probably concerned with a ferruginous geode "a globular mass of clay iron-stone", ${ }^{38}$ and Pliny actually mentions ${ }^{39}$ a stone which he calls geodes, as being useful as a remedy for the eyes, and for the cure of diseases of the testicles and breasts, but just what this was I do not dare to conjecture.

It is quite in accord with ancient ways of thought that the aetites, like other stones of strange origin, ${ }^{40}$ should be valued as a preventive of miscarriage. ${ }^{41}$ We are assured that there were always two of them in the nest, a male and a female stone, and that, if they are not there, the birds cannot reproduce, and that, being two, the young they have are always two. ${ }^{42}$ Of four kinds of eagle-stones which our author describes, one, the Taphusian, is to be found in streams. If this be attached to a pregnant woman or animal in a piece of skin which has been taken from an animal that has been used in a sacrifice, and be kept in place to the time of parturition, it prevents a miscarriage. If removed, however, before that time, it causes falling of the womb; if not taken away after parturition has begun, it prevents birth entirely. ${ }^{43}$ To this very day in Italy "pregnant stones", pietre gravide or pietre della gravidenz $a,{ }^{44}$ found, it is still reported, in the nests of eagles, are let by midwives for a fee to women during pregnancy. ${ }^{45}$ Fastened to the left arm or hip, they are -expected to protect her through the period of gestation, ${ }^{46}$ nor does this blessing end with the delivery of the baby. The nursing mother should wear one suspended from her neck if she expects to insure her infant a good supply of milk. ${ }^{47} \quad$ It is perhaps only an indication of an abnormal ecclesiastical leniency when such obviously pagan amulets appear among the ex-votos exhibited in a church. ${ }^{48}$

It was a usual belief in antiquity that the three chief times of danger in the career of a man, so far as those which come from sorcery and the spirit world are concerned, are birth, marriage, and death. The natal hour seems to offer the maximum menace 
of the three. We of today try to reduce infant mortality to a minimum by applying the results of scientific study to safeguard delivery and the crucial periods before and after. But the Romans resorted to much simpler and probably, in some cases, to what were really less dangerous devices to protect the two persons most involved. For example, it could do the woman who was lying in no harm, at any rate, if somebody threw a stone over the house in order to ease her suffering by an act of magic. ${ }^{49}$ Presumably this would scare away any evil spirit who was hovering around. If in the Italy of our own time a relative of a woman in travail steps to the window in her chamber and with a fierce look around at the possible witch or witchcraft in the air spits out three times, he is observing due precautions of a similar nature and not merely indulging a personal habit or relieving a supercharged gland. ${ }^{50}$ In the region of Perugia there is current a rather simple prescription against miscarriage. The woman has merely to wear from the first months of pregnancy in contact with her abdomen the skin or a part of the skin of a calf taken alive from its mother's womb by a Caesarean operation. ${ }^{51}$

Among ancient protective charms were certain small bones which we are told were found in the heart and uterus of a hind. This animal taught mankind their utility by swallowing them at some time during her own gestation period. ${ }^{52}$ Pregnant women were much indebted also to the wolf. Not only was its fat praised as a fine emollient for the womb and its liver used in some way or other as an anodyne for uterine pains, but; as the woman neared delivery, she should eat some of its flesh as meat, and during childbirth see that some person was near her who had done this: it would nullify any noxious spells. On the other hand, it could work the parturient woman great harm if that person should chance to arrive on the scene just at the birth. ${ }^{53}$ Even in the midst of her pains she might have to take a dose of dung, that of a wild boar or a pig, powdered and sprinkled in her drink. ${ }^{54}$ A mixture of sow's milk and honied wine is said to facilitate parturition. ${ }^{54}$ So, too, goose dung and the uterine discharge of a weasel. ${ }^{55}$

In antiquity there was a custom of giving a woman a key as a symbol of easy parturition, in other words, an instrument for unlocking and opening. ${ }^{56} \mathrm{~A}$ key in my collection of antiquities from 
Roman days makes part of a bronze finger-ring. The combination may have been merely a convenient device to prevent loss, but some would identify it as an amuletic charm. ${ }^{57}$ A key still serves as an amulet of release for those who are blessed with faith in occult action of a magical sort. It is reputed to relieve an epileptic of his falling sickness, free a baby from convulsions, send the blood to a limb that is numb and stiff, and assure a nursing mother a good flow of milk for her child. ${ }^{58}$ Putting a female key frequently in the hand of a baby is now said to make it able to talk soon. It releases that flow of language which men who wish to do the talking complain is natural to members of the female sex..$^{59}$ I have known the $\Phi B K$ key, dangling from a watchchain, to be mistaken even by an Italian professor for some sort of American amulet, "Philosophy, the guide of life", notwithstanding; but precisely what a key could do for a full-grown male who spoke soon enough, and could neither throw fits, nor bear or nurse a baby is beyond conjecturing.

Under the pillow of an Italian puerpera, it is quite possible to find concealed, if one has chanced upon a properly superstitious woman, not only a key, but also a piece of iron, a bone from the dead, some salt, and various sacred objects which are thought to protect her against witchcraft and to ease her delivery. It is also a modern protection for her against the machinations of a witch to put a piece of a priest's stole, a broom, and the skin of a badger behind the street door. ${ }^{60}$

Useful, also, at the time of confinement, if we may believe ancient lore, was a stick with which a frog had been struck out of the mouth of a snake. This operation of delivering one reptile from the other was expected to work by sympathetic magic upon the delivery of a baby. ${ }^{61}$ The choice of animals does not seem quite complimentary to either mother or child. Snakes play a role in obstetrics for other occult reasons, as we shall presently see, but just how the Roman applied that stick to a parturient woman we are left to conjecture. However, I have learned that nowadays a properly instructed Italian need merely touch the skin of the woman's belly with a walking-stick with which a viper has been slain. ${ }^{62}$ Actually, this may well be merely a modern version of the old practice. It is certainly a more agreeable way to ease a parturition than fumigating the parts involved by burning bran, 
horse manure or cowdung, as may also be recommended by Italians who claim to be wise in such matters. ${ }^{62}$

Pliny informs $\mathrm{us}^{63}$ that when a woman's delivery is to be expected soon, the husband can quicken it if he unties the girdle of his tunic and, after putting it around his wife, frees her from it, uttering the set formula "I have fastened it and I am going to loose it", and thereupon takes his departure. As a matter of fact, other advice in Pliny upon magical effects that may result from any sort of constriction would suggest that until his wife had been delivered and was sound and well, the man of the house had better stay around and safeguard her against careless visitors; for we are told that when a woman is lying in, or a sick person is taking medicine, nobody ought to sit near the bed with his fingers interlocked, or, worse still, with them in that position clasped over one or both knees, nor, indeed, should anybody in a sick room cross the knees at all. ${ }^{64}$ Whoever participated in the rites of Juno Lucina as the goddess of lying-in women must have nothing on the person in the form of a knot. ${ }^{65}$

Nowadays there are Italian women who during pregnancy would not dare to put a skein of wool or any knotted cord around their neck lest the child be born with the umbilical cord around its throat suffocating it, or, in any case, be fated to have a neck that is permanently undersized. ${ }^{66}$ The presence of maidens is undesirable, since their organs have never had the dilation of childbearing. ${ }^{67}$ On the other hand, there is a supposedly efficacious method of facilitating delivery by fastening around the parturient woman the cast-off skin of a snake, or by giving her a bit of it in her soup: then the baby slips from the womb quickly like a snake from a hole. ${ }^{68}$ This sort of obstetrical magic has a long history behind it. According to the Roman superstition, the circling slough had to be removed as soon as the child was born. ${ }^{69}$ The skin was thought to work effectively also if some of it was taken in wine with frankincense as the other ingredient. Administered in any other way, it was said to cause a miscarriage. ${ }^{69}$

Latin literature informs us of other remedial agents that should be available at parturition. To accelerate a woman's delivery the echeneis should be worn as an amulet, ${ }^{70}$ a vulture's feather should be put under her feet, ${ }^{71}$ or an ass's hoof should be burned beneath her, but only when a dead fetus is to be expelled. ${ }^{72}$ 
Other vile fumigations and repulsive potions recommended for this purpose depended upon the use of such things as excrescences from the legs of horses, their hoofs, and their dung. ${ }^{73}$

An Italian amulet against uterine pain is the first tooth that was shed by one of the mother's own children. ${ }^{74}$ For the same purpose a girdle that is made of sealskin may be worn. ${ }^{75}$ But in neither case can I guess at any possible line of reasoning that can go on about it in a user's mind. Perhaps it comes to nothing more than a willingness to try anything when in desperate pain. Mere strangeness may be a recommendation for a remedy among ignorant, superstitious people.

Romans believed that a taper kindled in honor of Candelifera kept away the evil spirits. ${ }^{76}$ These seemed to have disliked the light and the smell of lights. They were thought to be particularly pestiferous during a woman's pregnancy and parturition. In Italy there is still current a strong belief that a light must be kept burning constantly to safeguard the baby against demons until he has received the protection of baptism. ${ }^{77}$ Once he is made a Christian, he is relatively secure against the powers of darkness. But there are also, I need hardly add, purely religious reasons that prompt a pious Roman Catholic to keep an oil lamp or candle which has been blessed attached somewhere to the woman's bed. ${ }^{78}$ Moreover, holy water must be at hand to use, if an emergency should arise, for the baptism of the newborn child. The rite may have to be performed by either doctor or nurse when there is no priest living near enough to arrive in time in answer to a summons. ${ }^{79}$

When a Roman woman was in the pangs of childbirth, she would regularly turn for support to one of the major divine powers, Juno Lucina or Diana Lucina, goddesses who brought babies safely into the light of day $(\operatorname{lu} x)$, quite as in Rome, at this writing, parturient women address themselves to the Madonna in Santa Maria Maggiore. Some antiquarians have thought, indeed, that that great basilica occupies the site of a temple of Juno Lucina. A table of food was set out for her, after the woman whom she had been helping in the birth of her child had had a successful issue. ${ }^{80}$ Some deliveries must have given the goddess a sharp appetite. Two other divinities, Pilumnus and Picumnus, received a similar collation. ${ }^{81}$ Two thousand years 
ago a famous sanctuary of Diana on the shore of Lake Nemi was much frequented by prospective mothers. Ex-votos of terra cotta which have been found on its site represent women, some of them pregnant, others holding their newborn infants. They are offerings of gratitude from votaries who bore their bouncing babies safely and gave the goddess the memorial which they had promised. The nymph Egeria also received sacrifices from pregnant women who wished her aid during their confinement. ${ }^{82}$ This attests a feeling that even minor powers should not be ignored when need for supernatural support could be so dire.

Italians believe that among the saints it is Anna, the mother of the Virgin, who takes especial care of a woman at her crucial hour. ${ }^{83}$ The prospective mother may have the picture of this protectress removed from the head of her bed and put near her where she can see it readily at all times for her greater comfort. At her neck she should wear a medal of the saint and perhaps also one of the Madonna di Pompeii. Resting on her bosom she ought to have prayers in printed form along with accounts of miracles which Anna has performed, a source of confidence and courage, but also, one may fancy, a suggestion to her helper of what she expects from her at a crisis when the doctors may fail. Such narratives are to be bought from the "story-singers", cantastorie. There are also wandering peddlers who sell these modern sacra, the giramondi, who frequent places where people gather on the days of festas and fairs. ${ }^{84}$ When persons enter the woman's bedchamber, they are expected to say to her: S. Anna benedetta vi aiuti, "May Saint Anna, the blessed, assist you", if they are to be truly welcome. ${ }^{85}$ Words of good omen are important, and Italians have-so at least I have always found-a special gift for doing and saying the ingratiating thing in all relations of life.

At the crisis of her suffering a woman of Modica resorts in prayer to a specific Madonna, Madonna della Catena, my Lady of the Chain, to loose her from pain. ${ }^{86}$ The idea that one may have her own private Madonna, an, as it were, much particularized power, is very general among Italians. The many epithets of the Holy Virgin attest and further this attitude of the pious.

The very multiplicity of Roman divinities of all degrees of power was conducive to anxiety as to whether, in any given case, the right one was being chosen for one's petitions and worship. Among 
tutelary deities of married people, di coniugales, and of infants, infantum di, were the two brother powers already mentioned, whom the Romans named Picumnus and Pilumnus. The former was the personification of the woodpecker (picus), the latter of the pestle (pilum). Their protection was needed against Silvanus, who was a wild and mischievous spirit of the woodland. We read of a special ceremony which was performed after a woman had given birth to her child, in the invocation of Pilumnus and of two other friendly spirits, Intercidona, the "Sunderer", and Deverra, the "Sweeper." It required three men to attend to it at the entrance of the house, that being generally recognized to be always a place of danger. One struck the threshold with a pestle, another with a hatchet, and the third swept it with a broom. These three implements, tokens of civilized life, used in this performance of avertive magic were thought to keep the spirit of the savage wilds from coming in. ${ }^{88}$

But in Roman antiquity no fewer than twenty or more other divine beings presided specifically over the first life of a child; for it seems unreasonable to suppose that the names of those that are mentioned in Latin literature, Rumina, Adeona, Abeona, etc., figured in the mind of a worshipper as merely epithets of this or that major divinity and not as the appellatives of distinct, independent powers. $^{89}$ Of course, at first thought, from the usual scientific point of view, we should condemn the entire score of spirits as so many powerless nonentities, but actually the Roman's confidence in some of them and their like could be salutary as compared with the trust that might be placed in some ignorant physician or midwife; for the combination of the two mortals could easily be responsible for the death of both mother and child through their active incompetency or quackery. Similarly today a saint can be a very real presence in the thought of a trusting contadino. Even one who discredits the whole system of intercessors must recognize that, however illusory the sacred visitor may be, Santo This or Santo That will never work any direct harm. It is usual for a pious Roman Catholic to invoke a special saint, for example, San Leonardo. By a popular twist to observe the proprieties, he may be called Santa Leonarda. ${ }^{90}$ If his or her intercession fails to facilitate delivery, it is time to turn to other saints of either sex, particularly, in many communes, to S. Francesco di Paola. They 
may appeal also to the Madonna and even directly to God, although direct addresses to the Supreme Deity are not, perhaps, so usual in Roman Catholic circles as in Protestant.

Let us consider now some Italian practices which have nought to do with religion and are more or less replicas of ancient practices in their spirit and certainly, in some cases, in their futility. It is, indeed, pathetic to see how prone many ignorant mothers are to turn to those who are reputed to be adepts in the operations of magic rather than to the ministrations of a physician in their time of special need ${ }^{91}$ for the best of medical care.

Collectors of folklore have noted some of the obstacles or rather of the supposed obstacles to a favorable delivery which superstitious Italians dread. For example, they deem it perilous to have in the house of the woman who is lying in a member of her sex who is of ill repute, in other words, una donna in disgrazia di Dio, ${ }^{22}$ or a female hunchback for fear of the power of the evil eye that is credited to her, the ever-dreaded malocchio. No squint-eyed woman should be allowed to enter the bedchamber, nor a woman who has come with her distaff engaged in spinning, since the parturition will continue until the hemp or the wool has been spun, and the spinster's mere coming must be taken as a hostile act. ${ }^{93}$ It is not safe, either, to have a midwife, mammana, who is wearing mourning. ${ }^{94}$

Always to be feared at this time are the evil influence of jettatura, maleficent overlooking, and the workings of sorcery, stregheria. Against these threatening perils Giuseppe Pitrè, speaking of his fellow Sicilians, lists a number of protectives, including the use of saliva. This is an ever-dependable avertive, provided it be spat under precisely the right conditions. No matter how many amulets an Italian may wear, the product of his salivary glands can always reinforce their power. ${ }^{94 a}$

While they are trying to avert various mystic terrors, those who are attending a woman at her parturition can do some pretty dreadful things. A doctor of Perugia tells how the common people thereabouts sometimes seek to hasten the pains of their friend's delivery by giving her a shock. Un forte spavento may be contrived by putting in the woman's soup (minestra) a huge spider, a lizard, a snake, a toad, or a mouse. ${ }^{95}$ Sometimes it suffices to make her sneeze by sniffs of snuff. ${ }^{96}$ 
Similia similibus curantur, "like cures like", is sound doctrine in magic, with a very broad application of the principle: one needs no great amount of imagination to find some sort of connection between a disease or other physical evil and an occult cure that may be recommended. Sometimes a similarity between the remedy used and the result to be obtained is not at once apparent to an investigator, but among the cases which can be adduced from modern as well as ancient therapy there are many in which at least a superficial correspondence or some sort of mystic analogy is discernible. For example, the woman who is pale from the hemorrhages of parturition may expect to recover her color, provided she wear something red, but she must avoid anything of a different color, and especially a mixture of colors, lest she finally leave her bed with a mottled face. ${ }^{97}$ In some instances, color is only one of the factors in the service that the object performs. A red ribbon round the body, la misura di San Sebastiano, i.e., the chest measure of the saint, is declared a cure for fever, while the dark gray cord of San Francesco di Paola, when fastened around the waist of a woman in confinement, is thought to insure her a happy outcome to her travail.98 In the latter case it is perhaps the saint alone and not at all the color which should receive the credit for success: I should not dare to guess at what is in any Italian peasant's mind, even when she is not bearing a child. It is only after eight days have passed from the birth of her baby that a properly superstitious Abruzzese woman will comb her hair, and, if she does not wish to lose her hair, she will have under her feet, as she combs it, a piece of iron, e.g., a spit or hatchet, which has been heated. ${ }^{99}$

But it is time for us now to imagine that the infant has been born, that the mother is doing as well as could be expected, and that her offspring cannot receive too much attention from us in the opinion of either old Roman or modern Italian parents.

According to the ancient mythological story, Athena sprang to life, full-grown, from the head of Zeus, and the thought may well occur to an imaginative student that a large part of the populace of Rome in ancient days must have had a similar birth of full maturity, since Latin literature has so little to say of the life of children, and the sculptors of Rome have so infrequently given us their portraits. But we may be sure that Italian communities of those days teemed with boys and girls, and the references to them 
that we do possess declare their importance in the life of their elders, and, in some cases, reveal an emotional tenderness which one expects to find in a modern Italian, but perhaps not in the old Roman with whom we associate the cruelties of war, the gladiatorial games, and the wild beast fights. In some delightful lines with which Vergil ends his fourth Eclogue he urges the baby who has caused his mother ten long months of travail in bearing him to begin to know her with a smile:100 "Those who have never smiled on their parents, no god honors with his table, no goddess with her bed." The Tuscan peasant calls the sudden fleeting smile which a mere infant sometimes gives, benedetto, "blessed." The little innocent sees the angels whom we cannot see. ${ }^{101}$ If a butterfly appears near the cradle, the Calabrian recognizes it as an angel, or some baby's soul. ${ }^{102}$ Prosaic doctors may say that the smile comes simply from baby's sense of well-being, but Italian mothers and discerning poets will always see in it something of heaven, something divine. On the other hand, a habitual smiling in the first forty days of life is interpreted by the superstitious to be a sign of coming misfortune. ${ }^{103}$ Indeed, if a baby is in poor condition and will not be quiet, or, on the other hand, is prone to smile during the first forty days, it may be suspected of being a changeling. ${ }^{104}$ Either the Devil is responsible for this, or some witch. Parents who are convinced that the child is not their own must work on any suspected person with gifts, and place the changeling at a crossroad in the hope that the witch, moved to pity, will return the mother's own child and take back the weird substitute. ${ }^{104}$

The ancients were too much interested in omens not to be impressed with the fact that life begins with a cry, and some maintained that the much-talked-of smile of infancy-risus praecoxille, as Pliny the Elder puts it-comes to no child until he has had forty days of life. ${ }^{105}$

The student of Roman art is tempted to interpret the fondness of the Romans for the baby forms of the god Cupid and of cupids in their sculpture and mural paintings as evidence of that same special fondness for children which is illustrated by the popularity of the Bambino conception of Christ in the iconography of Christianity in Italy. For the inspiration of piety there seems to be in that land more dependence upon representations of the Madonna and her chubby Child than upon those grim pictures of an emaci- 
ated and suffering Savior which are so abundant in northern art. Foreign observers comment upon the devotion of Italian parents to their offspring and upon the general happiness of domestic life. Holding the baby is still a preferred pleasure in an Italian family, and, among the poor, the older children are more likely to be quarrelling for the possession of it, with the privilege of smothering it with insanitary kisses, than for their turn at playing with a mere inanimate thing, such as a toy or doll. Yet every Italian girl knows that, if she only loves her doll enough, she can make it alive. It is needless to add that in the higher walks of life spoiled children can be obtrusively noticeable. They are the inevitable product of such doting parentage. ${ }^{106}$

When a child was born to a Roman family, it was customary for father and mother to declare their joy by having the door of their dwelling adorned with a wreath or with garlands of flowers. To sentimental people of our time the custom might seem to be lovely enough to adopt, were it not that a spray of flowers is already used in connection with crepe to announce the arrival of that least welcome of visitors, Death. It is, indeed, a sad commentary upon the poverty which prevails in parts of Sicily that the black of mourning has sometimes been displayed at the door of indigent parents when they had to declare the addition to the family of a baby girl - the unwanted girl.

Italy is such a conservative land that the motives given for a certain custom may change in the course of the ages and the original reason for it may be lost to knowledge, and yet the custom itself live on. Those superstitious parents in various parts of the kingdom, as, for example, in Amalfi, the Abruzzi, and Sicily, who have kept up the practice of placing a newborn child on a cloth spread on the earth or floor, generation after generation, probably do not even know that they had predecessors long before the commencement of our era who were doing the same thing. ${ }^{107}$ The Roman belief seems to have been that through lying there the infant drew strength from old Mother Earth as the parent of all living things. ${ }^{108}$ We hear of the divine spirit Levana as being present, if she had been properly invoked, to preside over the lifting of the child from the ground-her only service during the entire lifetime of an individual-a momentary god, indeed!

Italians are to be found whose ways of thought are so primitive 
that, soon after a child has been born, they will put it on the ground or beneath the bed with the idea that this mystic act will safeguard it against having convulsions, or they will lay it upon snow to preserve it from chest affections, or to make it permanently fearless of cold, ${ }^{109}$ or, if it be a boy, they may wrap him at once in his father's night shirt in order to insure that he live sano $e$ robusto. ${ }^{110}$

Upon the arrival of a son or daughter in the Roman family, the nurse in charge laid it at the feet of its father. He might acknowledge its paternity and his desire to rear it as his own by taking it into his arms, or, because of what seemed to him to be a compelling reason, he might let it lie on the ground where the nurse had put it. This would signify that it was to be exposed in some public place to die, or, if such were its fate, to be found and reared by somebody else who had desired a child, or who was too tenderhearted to let it perish, or who saw a chance, especially in the case of a girl, to bring it up for gain through the fees of prostitution.

The mysteries of birth have always had a fascinating interest for superstitious people. In Roman days the production of a monstrosity in either the human race or in the animal world portended something momentous for the whole community, ${ }^{111}$ such creatures as a pig with a human face, or with two heads, a colt with five legs, a baby without arms or feet or one two-headed. The birth of what passed for a hermaphrodite might be of national importance: it was an awful threat. ${ }^{112}$ Such a baby had to be kept out of all contact with the earth, enclosed alive in a chest, and cast outside of Roman territory into the sea. Those who look upon the birth of the Dionne quintuplets as a supreme good fortune, a truly "blessed event", should read what Capitolinus says in his biography of Antoninus Pius:113 "The following misfortunes and prodigies occurred during his reign. . . . The Tiber overflowed its banks, a comet appeared, a child was born with two heads, and a woman gave birth to quintuplets." Even the birth of quadruplets to a certain Fausta at Ostia in the reign of Emperor Augustus was deemed to portend a famine which presently befell Rome. ${ }^{114}$

During the Republican period of Roman history exposure of an unwanted infant was quite unusual, but its immediate death by drowning was probably in all periods the approved disposal of it if the infant was born either a helpless monstrosity or a hopeless 
imbecile. ${ }^{115}$ The practice in modern Italy, as elsewhere, of saving such a miscreation because of its possession of an immortal soul would have seemed to a humane Roman an unpardonable wrong to all concerned.

The abandonment or murder of children has been a persistent criminal problem with which every age has to deal wherever poverty is rife or loose sexual relations are common. Through all the Christian centuries the Church of Rome has done what it could to discourage desperate mothers from doing away with their offspring. Recognizing that a degree of maternal instinct can survive the ruin of hope and character, the authorities have offered this natural feeling a chance for at least a partial satisfaction. Without revealing their own identity, mothers have been able to preserve the life of an illegitimate child by going by night to the entrance of a foundling hospital or asylum and placing it upon a revolving shelf or in an arrangement resembling a cradle, the ruota. As this turns, it carries the baby through an aperture out of sight to be received by the nuns of the institution and properly cared for. This simple device to protect life and good name I have seen at the portals of the Ospedale di Santo Spirito in Rome, although it may now be no longer in use. ${ }^{116}$ Through this invention for the preservation of secrecy and anonymity children up to the age of seven have received a convent mother in lieu of their natural one. At Naples, however, the authorities in charge of an asylum had, at last, to close an aperture of eight square inches, because there were so many attempts made to squeeze through it children who had grown too large. Though naked and well oiled, some of the victims were extracted crippled for life. ${ }^{117}$ As a matter of fact, whatever be the reason, infanticide has been, it would seem, exceedingly rare among the modern Italians. ${ }^{118}$

It may not be generally known among classical students that the opportunity for parents to rid themselves of an infant with a minimum amount of inhumanity may have ancient precedent. In the excerpts made by Paulus from the dictionary of Festus we read of a so-called Columna Lactaria at Rome, where, if our interpretation be correct, babies might be put to be taken and reared as foundlings. ${ }^{119}$

Quite as some foresighted parents did in Greek and Roman days, when an unwanted child was exposed to die or to be found, as 
chance might decide, the Italian mother has sometimes left with her baby or on it some object which would identify its parentage if a turn of fortune or the prick of conscience eventually inspired the wish for its recovery. So in the home for foundlings, Casa dei Trovatelli, of an Italian city, a token of identity, known only to the person who gave up the infant and the managers of the institution, has, in some instances, led to its restoration. Commonly the identifier is a ribbon of unusual color or a piece of money which has been cut in half. The claimant has only to match the ribbon or the half coin with what she has retained in order to secure her child. ${ }^{120}$ The practice of deserting children greatly exercised both pagan and Christian moralists in antiquity, not only for more obvious reasons, but because of the future danger of committing an unwilling incest: a girl grown to womanhood might marry her own brother, a father fornicate in a brothel with his own child. ${ }^{121}$

The preference which the Romans showed for male children and their greater willingness to rid themselves of a girl baby than a boy, if the birth of any offspring was undesired, or if its prospects for a healthy life were poor, is not without parallel in civilized form among many Italians now. A child of the stronger sex bids fair to be an asset, one of the weaker a liability. And so down in the region of Venosia ${ }^{122}$ (not to speak of other communities) the wish of felicity takes the form of salute, denari e figli maschi, "Health, wealth, and male children"-and Venosia is Venusia, the birthplace of Horace, Rome's poet of worldly wisdom, who, apparently, never married. When a Sicilian bride enters her new house, her friends may call to her cuntintizza e figgi masculi, which is to wish her contentment and boy babies. ${ }^{123}$ In Sicily the salutation of good omen for a sneeze may be Salute e un figlio masche, "Health and a male child." Nobody, of course, would sneeze for a female.

In order to obtain their preference superstitious women may wash themselves and fumigate themselves, using for bath or smoke aromatic herbs that were gathered on the day of San Giovanni, the day of magic, and they drink decoctions of Mercurialis annua, or eat the kidneys of a hare. ${ }^{124}$ Some even cherish the comforting belief that the sex of their infant can be determined at any time right up to the moment of its issue. The woman need merely hold in her hand the pestle for salt to bear a boy, a brush or broom to get a girl. ${ }^{125}$ Superstitious methods of prognosticating the result 
of their efforts abound. ${ }^{126}$ In all of this they are true descendants of Roman women who would drink decoctions of plants ${ }^{127}$ and eat parts of such animals as hares and cocks ${ }^{128}$ as sex determinants, and resort to senseless forms of divination ${ }^{129}$ to learn what success was in store. Since there was, we may suppose, nearly a 50-50 chance that the prognostic would turn out true, luck might give any method a considerable reputation. According to ancient diviners, even to dream of a son was better than to dream of a daughter. The vision of a girl implied the need of providing a dowery, and she was, therefore, as it were, a sort of creditor. ${ }^{130}$ Nor is it without significance to a person of fancy that the namingday of a girl was the eighth day after birth, while a boy's was on the ninth. An extra twenty-four hours needed to settle on his praenomen! In Italy of the present, the Christian present, the baptism of a boy is likely to be esteemed the more important. ${ }^{131}$

One of the tales of Greek mythology that delight our fancy by the naive criminality which is set forth in them tells how Cronus acted like a jack rabbit, eating his children as fast as they were born. When his wife Rhea gave birth to Zeus, she defeated this habitual cannibalism by handing him a stone, swathed in strips of cloth, which he thereupon swallowed, quite unaware that he was still the father of a living infant. Even if we wish to fancy that Cronus, as the aged God of Time, had reached an extreme stage of senile gullibility, it is hardly comprehensible how he could have been deceived by such a substitution. But the myth does become a little more reasonable as soon as one has seen with his own eyes the likeness to an elongated medicinal capsule which a Greek or an Italian infant often bears when it has been wound with a swaddling-band some five inches wide and several yards in length. When baby's one piece garment, fascia, is flying from a clothesline on a Neapolitan roof, or is hanging in all its undulating length from the rail of a balcony to dry in the sun, a foreigner who is a stranger to Italian ways could readily mistake it for a pennant, a homemade decoration for some festa. Still more do the bands resemble pennants when they have received the maternal tribute of "Gioia Mia", "Delizia Mia", or "Idolo Mio", interwoven in the material, words of endearment and good omen for which no mother who reads aloud the words can need any translation from me. Two thousand years ago the bands were sometimes dyed in color: an 
imperial prince might be wrapped in purple. ${ }^{132}$ Since the child's arms as well as its legs are often and were often confined by the swaddling-band, the resulting bundle would look almost as much like the stone of Cronus as like an infant. ${ }^{133}$ Even an Italian who is in the helplessness of a first fatherhood should handle his infant thus stiffly swathed without fear of breaking it, but he must be sure which end is which, if he tries standing it upright in a corner, as he may be tempted to do in the child's squally moments. When one who is familiar with the art of Italy sees one of these bundled babies, he will think at once of some favorite bambino made of glazed terra cotta which he has admired in the tympanum over a church door in Tuscany, or perhaps in some art gallery where a room serves as a crèche, shall we say, for the lovely children of the Della Robbias. ${ }^{134}$

The continuity of this method of clothing infants through hundreds of years can be traced in Italian paintings, but nowadays one must not look for exemplifications of it among babies who are born with the proverbial silver spoon in their mouths. Tinspooned Mussolini may have been bundled in this fashion in his humble birthplace at Varano di Costa, a hamlet overlooking Dovia di Predappio, but we imagine that his own grandchildren received a more ducal treatment and wore diapers.

Among the ancient writers Pliny the Elder contrasts man in his helplessness with all other animals, noting that they are born to complete freedom in the use of their body, while the human baby has all its limbs swathed in swaddling-bands. ${ }^{135}$ The creature that is destined to rule all others lies bound fast, hand and foot, in weeping impotence. Naturally observers who come from lands of diapered infants have often commented upon this Italian method of clothing them. Hawthorne conjectured ${ }^{136}$ that use of this binder was responsible for an excess of dwarfs in the population of the country, Charles Dickens that it produces cripples; ${ }^{137}$ but a far more trustworthy commentator, W. W. Story, held that it is wholesome and that it accounts for good backs and fine straight limbs. ${ }^{138}$

In Terracina, where winter can be sufficiently severe, I have watched little children, who were all but nude, playing gleefully in a large puddle of water, thinly skimmed with ice, which they broke with their bare feet. The representations of slightly clad children in ancient works of art suggest that young Romans were blessed with much the same hardiness. 
Just how long it was after birth that loving Roman parents began to put on their baby ornaments as well as garments can only be conjectured. I am tempted to believe that it may have been rather early because I have had pass through my possession, and have seen in collections of antiquities such tiny earrings and fingerrings. Certainly today among the Italians personal decoration begins early in life. In the third-class compartment of a railroad train you are likely to see a mere infant nestled in its mother's arms wearing in the tiny lobes of its ears a pair of rather heavy gold earrings. The illusion that it must be already pretty well grown up may be furthered by the sight of a piece of sausage which it is sucking in place of its thumb.

In Roman Catholic Italy it is necessary to make a new arrival in the world a Christian by baptizing it as soon as possible. Baby can be clothed and bound to a pillow, and, with its near baldness duly capped, be already on its way to the font within a few hours after its arrival in this world of $\sin ^{139}$ Only after the priest has finished the rite-so runs an Italian belief-should "the little darling" receive its first kiss-until baptized he may figure merely as un ebreo-and the promptness of his Christening is said to free a soul from Purgatory. ${ }^{140}$ During the inclemencies of the winter season, in order to avoid the risk of having sudden death from exposure consign the infant to Limbo instead of Paradise, it may be carried to the baptistery in a coffin-like box. It is visible through a pane of glass, while safeguarded against any current of air, that dread of hypochondriacs whom one can never hope to escape in train travel even in sunny Italy unless he rides thirdclass. In cases where the trip to church is quite impossible, an altar erected in the house of the parents may be used for the performance of the rite.

At the baptismal font, if the teaching of the Roman Catholic church be fully respected, the infant receives for its good fortune the name of a saint as its Christian name. ${ }^{141}$ The vocabulary of appellatives available has its limits. Consequently, if the patron saint of the place where he is born is selected to be his protector, and it happens to be, let us say, Giuseppe, an occasion can readily arise in his maturer years when his mother's call of "Bepe, Bepe", may assemble from various directions a considerable number of unwanted boys from whom to single out her own. 
The paucity of the Italian first names that are in common use recalls the limited number of patrician praenomina which were available to the pagan Romans. It also accounts for the importance of the nicknames to the use of which the Italians are so much addicted. It may, indeed, be the individual's nomignolo, contranome or sopranome, as it is used in place of Christian name and surname together, that best identifies him. The designation may have been attached to him during his childhood in goodnatured fun, or as a term of ridicule, or for some hostile reason. ${ }^{142}$ Even villages may be known to many only by their nicknames. ${ }^{143}$ The criminals of any of the large Italian colonies in the cities of the United States exemplify what extra work this habitual use of nicknames may cause police and detectives. We must remember, too, that, according to primitive ways of thought which persist, a person's name is so closely and intimately related to him, or, if we may so express it, is such an integral part of him that it may be used in the operations of magic to do him harm. ${ }^{144}$ So, for example, when a Roman was laying somebody under a spell, he would drive a nail through his enemy's name, written on a tablet, or, perhaps, inscribed on a likeness made of him in wax, and then hide this where his victim could not find it. If the person cursed came into possession of it, he might loose the spell by some counter charm. Today even the foreigner is likely to bear a nickname in the community where he settles. Some oddity about him stands out enough for a local wit to note it and dub him with a descriptive expression which people use behind his back. Overhearing it may profit him as a corrective of any pomposity or conceit, but, as a rule, Italians are too considerate of hurting an American's feelings to make this a common experience for one of us.

The nature of the third name of the ancient Roman, his cognomen, which designated his family, as the second name indicated his clan, suggests that it originated as a personal name and only later was given to all members of the family; for we have such names as Rufus, meaning the "red-headed man", Naso, implying that the person so named has a prominent nose, Barbatus, the "bearded fellow", all sounding like the nicknames that Italians would use today. Well-known is the name of the Roman emperor Caligula, which stuck to him from the time that his 
father's legionaries gave it to him as a little boy because he used to wear a child-size imitation of the heavy hob-nailed sandals of the common soldier. ${ }^{145}$ The historian Tacitus tells us of a brutal centurion whom the soldiers dubbed Cedo alteram, "Bring another", because when he had broken one vine-stick on a man's back, he would thus call for another, and then another. ${ }^{146}$

Pride in the noble history of their country has led Italians to adopt the names of many historical and legendary personages. They are not always, however, accurately bestowed. Thus-so I have been assured on excellent authority-at Pratica di Mare, the village which occupies the supposed site of Lavinium, the first settlement of the Trojans in Latium, mothers are prone to name their boy baby Didone, believing it to be a masculine word, and their girl baby Enea, which is, seemingly, a good feminine form. Irreverent school-boys in our land might think the interchange appropriate as they recall the ready tearfulness of pius Aeneas and the heroic end of Dido. ${ }^{147}$

Twenty centuries ago Italians were more leisurely about naming a new member of the family. As we have already noted, daughters commonly waited until the eighth day, sons to the ninth. I have been interested to find that in Venice an eight-day anonymity has been-at any rate, at one period-the custom for newborn children. We may note, finally, that the Romans made namingday an occasion for purification ceremonies, and there would be a jolly family party at which the infant might receive presents. All this is, in a slight way, an anticipation of modern baptismal celebrations.

In view of the important role which suffixes play in modifying the meanings of Italian words, the reader may be interested to know that the old Romans had already converted ordinary names into expressions of affection by giving them significant endings. So Julia became Julietta as a name of endearment, and we also find Gallitta and even Livilitta. Italians have therefore, excellent precedents when they ring into an infant's ears such affectionate diminutives as, bellillo, ninnillo, titillo, titiriniello, as well as make more musical even his own baptismal name. ${ }^{148}$

The special nourishment of mother and baby may now engage our attention. In these days when we hear so much about allergies, it is interesting to find an Italian superstition that before 
a mother makes her first visit to church after her delivery, she should have taken pains to eat a small amount of every sort of food to prevent any of them from ever being harmful to her offspring and insure for it a robust health. Grapes alone are excluded from her diet, lest eating them should develop in them both a tendency to get drunk. ${ }^{149}$

In pious homes of Italy an oil lamp of small size may be kept near the lying-in woman as a sort of silent invocation to the Mother of God to send her breasts a good supply of milk when the baby comes. Nearby is also l'acqua panata, toast in water, of which she takes a little every time she finds her misery too severe. ${ }^{150}$ Then, even in a matter of magic, something sensible may be done, although the motive for it be quite foolish. Buttermilk curds, ricotta, would seem to be wholesome food for a woman during her time of lactation, but it is to its milky whiteness that the superstitious attribute a peculiar potency in bringing a full supply to her breasts. ${ }^{151}$ In other words, sympathetic magic should be playing its role here as in so many other operations which may seem to an untutored observer to be quite innocent of any occultism. Eating lettuce (lattuga) brings the milk (latte), not merely because of the etymological connection between the Italian words for the vegetable and the fluid, but because of the milky sap of the plant. ${ }^{152}$ If the mother's nipples swell or indurate, the amuletic cure is a comb of ivory: for is it not as white as milk? ${ }^{153}$

If disease attacks her breasts, a superstitious woman of Valdelsa may turn to her experts in magic for a cure. They anoint them with preparations of herbs and rub them, while they utter the proper words of benediction. Any witch or warlock whom she consults must be recompensed with presents, not paid with money. ${ }^{154}$ In some places we learn that the dung of a mouse, taken in drink, has a good reputation as an agent to bring back milk to breasts that have gone dry, ${ }^{155}$ or, in order to achieve the same result, a bit of the afterbirth may be boiled in her soup without her knowing it. When the milk begins to come, it is well to take the placenta to a stream and hide it under a stone, so that, while no animal can find and eat it, the flowing of the water may insure a free flow of the woman's lochia. ${ }^{156}$ In some places, the afterbirth is buried under a fig tree so as to make certain that she shall have plenty of milk for her infant: an unripe fig is milky. ${ }^{157}$ If 
a mother suddenly goes dry, it may mean that a female animal has found the placenta and secured abundant food for its own young by merely devouring it. ${ }^{158}$

Should the magic of witchcraft and the remedies of folkmedicine fail the nursing mother, divine assistance can be sought in the local chapel of S. Benedetto. ${ }^{159}$ She does well to suspend from her neck a representation of that saint. In spite of his gender, he can insure her baby a bountiful provision. If, however, the mother does not feel quite sure of an effective intercession by the saint, she may wear a small round white stone veined with red which is perforated in the middle by a hole which was worn through by the water of the stream in which it was found. These stones are considered great treasures to be handed down from generation to generation. ${ }^{160}$ Sometimes it is a hippocampus or seahorse which she has _somewhere on her person. The fish should be alive or only recently dead. A bit of cloth, wrapped around it, protects it and reduces the offensiveness of its odor. ${ }^{161}$ Other lacteal charms are the "Madonna's herb" (Balsamita minor), and a cloth containing soil from a sacred place. ${ }^{162}$

The ancients set store by a milk-white stone which they call galactitis, this being a derivative from the Greek word meaning milk. ${ }^{163}$ Nursing women believed that it promoted the lacteal secretion. ${ }^{164}$ They would also attach one to the neck of the baby to better its flow of saliva. This ancient precedent would be reason enough why Italian women of our time should be resorting to the use of a white bead, or to an appendage of white coral. They also depend upon milk-balls, cut out of ivory ${ }^{165}$ or out of chalcedony, ${ }^{166}$ or one of its varieties, agate. ${ }^{167}$ Jasper is another milk-stone. ${ }^{168}$ If an amulet of white coral be worn suspended from the neck of even the infant, it ought, they say, to stimulate the mother's provision of milk. ${ }^{169}$ Additional aid may also be sought from Saint Agatha, because in her martyrdom she lost her breasts, however strange this reasoning may seem. ${ }^{170}$

When, in spite of everything that the fancy of doting parents and the suggestions of the ignorant can inspire them to try, an Italian nursling begins to waste away, one may conclude that a snake is sucking the mother's breast at night after putting its tail in the infant's mouth to keep it from crying. ${ }^{171}$

For the ailments of a mother which were connected with her 
nursing, Latin literature offers a sufficiency of crazy remedies. She might mitigate pains in her breasts by anointing them with goose fat ${ }^{172}$ or by merely drinking ass's milk. ${ }^{173}$ The milk of that animal might be dried and applied to them to increase the supply of milk. ${ }^{174}$ Eating the eggs of partridges was said to produce the same result. ${ }^{175}$

The paraphernalia and the personnel of the Roman nursery anticipated somewhat those of today, and some of the usages there seem to have established precedents for the Italians to follow ever since. Modern-looking cradles and sucking-bottles were already in use. Lullabies and nursery tales soothed children to sleep. In modern Italian there is a rich literature of these for use by mother or nurse. ${ }^{176}$

Weaning brought Roman children some variety in their diet, but we read of some practices in their feeding for which $I$ have noted no parallels in the Italian home of today. For instance, we read of ancient nurses who gave a preliminary chewing to baby's food. The morbific possibilities of that friendly service need be merely suggested to the apprehensive type of mother of our times to cause a shudder of horror. ${ }^{177}$ Nurses were accused of swallowing the food themselves, cheating their innocent charges by not emitting. This was a trouble with which owners of aviaries who raised thrushes for the market also had to contend when they depended upon similar professional chewers in the feeding of their birds. ${ }^{178}$

However welcome the rapidly coming babies may be to prolific families in the lower levels of Italian society, the mother (who must be said to be at least somewhat responsible for the child's existence) often seems to be doing her involuntary best to hurry it out of life by paying such little heed to the laws of health as: would hardly appear excusable even in the remote Villanovan period of Italian history. So far as diet is concerned, I may say that there is scarcely anything that outrages the normal practices of a scientifically conducted nursery that I have not seen done. Let me illustrate by a few examples from experiences of mine such as "personally conducted" American tourists are not likely to have. ${ }^{179}$

The occupants of a third-class compartment of a train should not be surprised to see the least attractive of his fellow passengers 
nestled in his mother's arms receiving from her a draught of sour wine (as a rule, of course, diluted) instead of milk. ${ }^{180}$ I have observed a tiny creature, still unweaned, greedily sucking a sausage with no premonition of approaching death. When tied around the neck with a string, it serves as a non-disappearing, or, at any rate, retrievable baby-comforter. A yearling is old enough to be given raw chestnuts to eat and have coffee as a beverage in preference to milk. But we must remember that among the Italian poor (except as immigrants in the Americas) caffè is generally not real coffee, but, for the most part, a substitute, made, e.g., from some sort of grain that has been roasted. If a young child cries for his share of ham, he gets it, and too often he gets it raw. A fare of onions may enable parents to find their beloved bantling more readily in the dark, but he receives it at a much more youthful age than any treatises on the diet of children would allow. Its sweet tooth, or rather those that are on the way, may be gratified with a bit of sponge cake dipped in wine. Where honey is added to the milk for the same purpose, it may be more wholesome for the child than cane or beet sugar. The Romans thought that honey and butter made an infant thrive: modern Italians agree to this. ${ }^{181}$ Two millennia ago butter was valued for the treatment of infant maladies, for example, as an ointment for the aches of teething, and, in general, it was, like sugar, classed among the medicines, not the foods. ${ }^{182}$

The attitude of doting indulgence which we observe in so many Italian parents in dealing with their children is in notable contrast with the stern discipline that characterized the family rule of early Republican Rome. Patria potestas gave the father in those days complete and absolute control over his entire household. ${ }^{183}$ Public opinion and the natural feeling of paternity tempered his exercise of the power under normal circumstances. But when today an observer notes precious Pepino as he accords to his nurse's orders at best only a long deferred obedience, and, with a full confidence based on much success, follows the nursery adage: "If at first you don't succeed, cry, cry again", he cannot help recalling from Roman history the opposite attitude, that paternal despotism of early times which is exemplified for us by the case of Brutus, who tried his sons for a plot against their native land and presided over their execution, or by the case of 
Titus Manlius who, when his son disobeyed orders by leaving the ranks to fight a victorious duel with a taunting foe, had him put to death before his own eyes. But carino Pepino is not executed: he is obeyed, fondled, and kissed.

Ancient conceptions of what was quite proper discipline for children permitted nurses to terrify them into subjection by threatening them with punitory visits of ghosts and ogres. ${ }^{184}$ In Italy of today the goblins who "get" bad children, if they don't "watch out" are some of them of excellent classical lineage. Thus, it is reasonable to believe that the bugbear Mammone is a direct descendant of the Mormo who probably during many centuries served the nurses of Greek and Roman children in their reigns of terror. ${ }^{185}$ Lamia was another one of the terrifying creatures of antiquity with the coming of whom disobedient children could be threatened. ${ }^{186}$ She still lives in her character of a terrorist. Furthermore, the much dreaded sorceress, the Impusa della morte, of whom Charles Godfrey Leland speaks in his interesting but not wholly reliable book on "Etruscan Roman Remains", must be a survival, in a way, of the Empusa that figures in classical literature. ${ }^{187}$ Orcus, the god of the Lower World, as well as one of the names given to it, survives in the folklore of south Italy as an old man who has a long white beard, teeth as sharp as nails, and hooked fingernails. ${ }^{188} \mathrm{He}$ appears in Sardinia as "Uncle Orcus", Ziu Orcu. When a child misbehaves, he is told that this monster will carry him off, fatten and devour him. Orcu is ably assisted by the ogre Zia Orca, his wife "Aunt Orca." His name may be pluralized, so that Orchi is equivalent in Italian to "hobgoblins", "bugaboos." 189

One of the functions of the so-called Saint Eliseo, who is to be recognized, I suppose, as Elisha, would appear to be to destroy bad boys, but he has not been very efficient at this task. ${ }^{190}$ We must not overlook the fact that even Befana, whom we recognize ordinarily as the Italian gift-giver of Christmastide, is not always a sort of female counterpart of our Santa Klaus, but can be summoned as a bugaboo to scare children. Effigies of her as an old witch, made of rags, are burned by the boys at the ceremonies of Twelfth-night. ${ }^{191}$ Other fanciful modern creations are Farfarelli, Mamucca, and the Monacello. Occasionally they are called upon to coerce the disobedient child. There is much traditional lore 
about them current among the Italian people which I cannot deal with here. ${ }^{192}$

Fata, the Roman Fates, now appear as Fate, of which the singular in Italian is Fata. They are often thought of as beautiful spirits in contrast with the aged crones who figured as the three Fates in classic times. They can be generous and full of fun. They will rejuvenate the old, beautify the ugly, and enrich the poor, but their vengeance for any slight is much to be feared. ${ }^{193}$ The other conception of them as little wrinkled vecchiettine who deal out to us good and bad does, however, still exist. ${ }^{194}$ In Abruzzese folklore we even hear of Sibilla as the chief of the Fate, a seducer of young men and a bugbear whose name is used in parental discipline of the very young: Zitto zitto che la Sibilla ti porta via, "Hush, hush, or Sibilla will carry you off."195 Presumably to be associated with the Italian Fate are the spirits that are called Fatuzzi. In order to protect her baby against them a mother of Trapani in Sicily will put around the left arm a circlet of amber or glass. This carries as amulets a bunch of coral horns with fastening of gold or silver, along with seashells, little keys of silver, and other baubles which have been blessed in her church in spite of their patently pagan background. It seems that God punished the Fatuzzi for boasting equality with Him at the time He came on earth. ${ }^{196}$ San Michele Archangelo evicted them from Paradise, and, in these days, they make midair their place of habitation. ${ }^{197}$ Their attitude towards man is now kindly, now maleficent. They are thought of as tiny gnome-like creatures who lie with women. They seem indeed, to be as incontinent as a Roman Fire Spirit (the Lar Familiaris?) might be, or as certain Italian folletti. ${ }^{198}$

The utter helplessness of an infant and the constant exposure of growing children to injury when they have little foresight of their own to prevent it have led parents in every period of Italian history to safeguard them not only by human watchfulness and care, but also by the protection of spiritual powers to whom appeal could be made in prayer and, when success had attended the petition, some return of gratitude could be made in the form of a votive offering or religious sacrifice.

Everybody possessed of any cultural education is familiar with the names and fields of interest of the major gods and goddesses 
of Roman worship, but my reader may not know that, just as the Roman Catholic of Italy has many specializing saints upon whom to call in time of trouble, so the ancient Romans worshipped many minor spirits each responsible in a particular field of activity. From the time of birth on, the child came progressively under the care of such powers: Cunina safeguarded him as he lay in his cradle, Potina presided over his drinking, Edusa over his eating, Statilinus assisted him to stand erect so that he would not become bowlegged or knock-kneed, and, as Vaticanus had been by him at his first cry, so Fabulinus superintended his first articulate speech. ${ }^{199}$ At that time the debate would start, we may suppose, as to whether pater or mater received the earliest address.

We have given only a sample of the divine protectors who were supposed to watch over the very young. If all were known to scholars, they might prove to be as numerous as the special saints of Roman Catholicism or as the fairies in which a Protestant may believe in a moment of poetic ecstasy.

But the worship of pagan gods and the reverence of Catholic saints are not nearly so interesting to some of us as are certain ancient and modern dealings with the spirit world which adherents of legitimate religion must ever disapprove. There is the great kingdom of magic, in which the professional experts have been the witches and warlocks who have gulled the simple-minded in every age successfully. The boundary lines between it and the fields of religion and medicine are not always easy to establish without some irritation on the part of those whose life's work lies in these two departments of learning. Even in our study of man's early years we are bound to give some attention to the ars magica and to some of the superstitions that are associated with it.

The Romans believed that children were exposed not only to the ordinary perils of accidents, bad health, and disease, but to various evils for which occult influences, operations of magic, and visitors from the spirit world might be held responsible. Witches might use the black art for nefarious purposes of their own, or put it to the service of clients who were intent on accomplishing something beyond the normal powers of man and, in many cases, something actually criminal.

In all their activities witches and wizards have been able to escape publicity by changing into animals or by using agents of 
demoniac character. Imagination has also created as possible dangers to infancy various beings who have more or less the nature of spirits. Their human traits and their names vary with the locality which cherishes lore about them. Let us review a few of them. Some of them have a long lineage.

When a Sicilian woman is nearing the time for the birth of her baby, certain knowing ignoramuses of her community may advise her to eat nine black beans, one at a time. After her child has arrived, the eldest woman present at her delivery should form a cone of nine of them on a table, and by reciting the proper conjuration render certain spirits, le padrone di casa, impotent to do her any harm. ${ }^{200}$ But of greater interest to us, of course, are the creations of fancy that have some background in the history of ancient superstition. Some of these, like Mormo, Lamia, and Orcus, and their modern representatives have already engaged our attention in another connection, but there are others who are equally dreadful.

The vampirical striges or strigae (the vulgar spelling), of whom we find grim tales told in our Latin authors, were, doubtless, born to primitive fancy from knowledge of screech-owls, blood-sucking bats, and other vermin of the air. ${ }^{201}$ In early times the pallor of an ailing child was not interpreted in terms of needed vitamins and minerals, but in terms of visits which such creatures of the night would make to it in order to feed on young blood. Witches took the guise of these flying things as well as of spirits in order to facilitate their undertakings. Cuts and scratches on the child, selfinflicted or not, would be credited to beaks and talons.. ${ }^{202}$ The belief was strengthened by the sight of screech-owls flying about tombs in the hours of darkness. The strident note of the bird would suggest to a superstitious Roman that the ghosts of persons who had died before their time were wailing over their unhappy fate and bent on vengeance. A few authors give us most of our Latin lore on the subject.

In a passage of his Fasti Ovid appears to have confused Cardea, goddess of hinges, with Carna, whose function was to protect the vitals of the human body. ${ }^{203}$ He tells us how Janus, after ravishing a nymph, constituted her the deity of hinges and assigned to her the task of safeguarding infants from the vampirical striges. These rapacious creatures with goggle-eyes and curved beaks fly 
by night and assail children if they are not sufficiently protected by a nurse. Their strident voices give them the name of strix. This is the Latin word for screech-owl. They seize an infant from his cradle, suck his blood, and devour his vitals. Ovid leaves it unsettled whether they are born birds or are not rather the result of a metamorphosis of beldames into that form under the influence of a spell imposed by some Marsian wizard. ${ }^{204}$ Although Pliny the Elder is credulous enough about many matters, he stamps as a fabulous invention the statement that striges milk teats into the lips of infants. ${ }^{205}$ However these things may be, the king of Alba Longa, Proca, was attacked by such creatures, as the story runs, when he was five days old, but the nymph Crane made him whole by touching the door posts three times in succession with arbutus leaves and marking the threshold with them thrice. She used water with some drug in it to sprinkle the entrance, and at the cost of a sacrifice of a two-months-old pig saved the baby's life. A sprig of white thorn, set in the chamber window, kept the birds from ever violating the cradle again. ${ }^{206}$

The term strix was used, then, for old hags in the flesh who practised the arts of sorcery and carried off the children. In other words, a witch was believed to turn into a screech-owl when it suited her purpose, as, in Italy of today, they change at pleasure into cats. ${ }^{207}$

We are introduced to a fiendish and possibly cannibalistic sorceress in one of the tales of horror which Petronius likes to bring into his novel here and there as spice to the narrative. A much beloved boy has died. His mother is bewailing his death with several mourners, when suddenly they hear the screeching of witches. At this a giant Cappadocian slave, who is described as strong enough to lift from the ground a mad bull, rushed boldly out of the house to attack them with a sword. He ran one of them through the middle. All heard the groan clearly enough, but they failed to catch sight of the witches themselves. When the man returned, he threw himself on the bed. His whole body was black and blue from the touch of the hag's evil hands, as if he had been scourged. When the mother went to embrace the body of her son, she found that she had only a little bundle of straw to put her arms around. There was no heart in it, no insides, nothing human at all. The witches had, it was only too clear, swooped down to take the boy 
and put a dummy in his place. The stout lad from Cappadocia never got back his natural color, and, a few days later, he died raving mad. Those who listened to this tale expressed alike their wonder and their full belief. They kissed the table, and prayed the hags of night to stay in their own haunts when the time came for the party to go home from the dinner. ${ }^{208}$

The Italian word strega clearly goes back to the Latin. It means not only a witch but also a vampirical monster possessed of the various powers which evil spirits commonly enjoy. ${ }^{209}$ In speaking of an anemic child a superstitious mother will say that it is stregato, in other words, that a strega has been working her bloodthirsty will upon it. ${ }^{210}$ Fortunately there is always available a plant that is thought to be almost a panacea in folkmedicine, rue, the "herb of grace." This has great magic power. Mothers have only to eat some of it on Ascension Day to keep away all the bloodsucking streghe that molest Italian babies. ${ }^{211}$ Incidentally we may remark that the mild cordial that is also called strega got its name from being a product of Benevento, which for ages has been the reputed gathering-place of witches. But Italians may use the word also for the wise woman who tells fortunes at a fair, or, at any time, in some public piazza, as I have seen her do, holding spellbound a wondering crowd.

Colitis and rickets are among the ailments of children for which ignorant Italians will hold witches and warlocks responsible. A skin eruption can be blamed on the meanness of some witch, who, finding baby's diapers or swaddling-band left out to dry after nightfall has urinated on them. The coming of Ave Maria should bring indoors every stitch of his clothing. ${ }^{212}$

About two parts of their anatomy other than their sexual organs superstitious people have felt some special concern from the most remote times, the hair of the head and the nails. ${ }^{213}$ This seems to have been partly because their readily recognizable growth suggests the existence of a special amount of life and vitality in them, partly because when they have been trimmed, the cuttings are thought to be so representative of their former owner that one can work the injuries of witchcraft against him by using them in magical operations. ${ }^{214} \mathrm{He}$ must, therefore, dispose of them in such a way that no enemy can get possession of them. $^{215}$ The teachings of superstition may furthermore require 
that hair and nails be cut at precisely the right time and in precisely the right way. For example, the principles of sympathetic magic indicate that they be shortened when the moon is waxing, not waning, if healthy growth thereafter is to be expected. This ages-old belief is, of course, world-wide! ${ }^{216} \mathrm{We}$ learn that a Roman mariner was strongly opposed to anybody's cutting his hair or nails on board his ship unless wind and wave were in angry conflict with each other. ${ }^{217}$ The day chosen for such self-improvement was a matter of importance to superstitious Romans ${ }^{218}$ and is a matter of importance even now to unnumbered Italians. Clipping the hair on a Friday makes it grow gray prematurely or fills it with lice. ${ }^{219}$ If, however, the first Friday in March be selected, the person will suffer no headache for an entire year. ${ }^{220}$ Similarly, while one should avoid cutting the nails on Tuesday, Friday, or Sunday, in order not to stop their growth, ${ }^{221}$ doing it every Monday, or, according to some, on the first Monday of every month should save one from a toothache for a twelve-month. ${ }^{222}$ Fridays must, however, be avoided even for a nail-cut. ${ }^{223}$

Besides these rules that are to be observed by everybody, no matter what his age may be, there are others which superstitious Italians follow in the rearing of their helpless babies. So, for example, Abruzzesi hold that one should not pare a child's nails before it is six months old, lest it grow up to be a thief. ${ }^{224}$ Other Italians make the period of uninterrupted growth a whole year. ${ }^{225}$ Moreover, it is wiser to bite off the ends of baby's nails than to clip them with the scissors. ${ }^{226}$

But it is time to turn our attention now to a specific superstition which has seriously affected the lives of the people of Italy (not to mention other lands) through some thousands of years, namely the superstition of the Evil Eye. The belief in it can still be a matter of daily concern. One finds it cherished not only by members of the lower classes but by many persons of social and intellectual standing, even as it was two millennia ago in Rome. Children were thought to be likely victims because of their inability to fend for themselves.

According to a usual doctrine that has prevailed through the ages, persons possessed of an ability to fascinate or bewitch by a glance of the eye may exercise this native gift either voluntarily, 
or, in certain cases, in spite of themselves. Possession of the power is commonly indicated by some peculiarity of the eye or by something unusual about the body, such as a deformity, or abnormal stature. ${ }^{227}$ An emanation of magic potency proceeds from the eye. This can be diverted, stopt, or nullified by various occult means. Quite usual is the employment against it of an amulet of some kind, a prophylactic gesture, or a countercharm of words.

Since feelings of jealousy are so often thought to be responsible for the action of the Evil Eye, possession of a healthy, pretty baby can cause an Italian mother as much solicitude as maternal pride. ${ }^{228}$ She has ever to fear somebody's lurking look of envy which may eventually cause her darling to waste away and die. So it is that quite spontaneous praise from anyone who is gazing at the child terrorizes the superstitious parent. A considerate Italian who is aware of all this will accompany his words of admiration, his Che bel bimbo, com'è bello! or the like, with some such expression as fuori jettatura or fuori malocchio, which orders the maleficence away, or he may call down God's blessing with a Dio la benedica or Il Signore lo benedica; for God's blessing is still believed to save a little girl or boy from the worst of deviltry. ${ }^{229}$ Merely to say Grazia a Dio, "Thanks to God", will suffice. If trust in God be feeble; one can always make the sign of the horns without attracting attention. This consists in sticking out towards the person or thing that threatens danger the index and little finger of the closed hand. This prophylactic gesture has been in use for at least several thousand years. It symbolizes, as it were, the actual horns of an animal, and these were deemed to be avertive as being instruments of hostility, or, it may be, as constituting a semblance here below of the crescent moon in the sky. This heavenly body in its waxing and waning symbolizes the power of growth. As an object of religion, it represents the Goddess Diana, and Diana, in her other self as Hecate, was mistress of Hell and Queen of Witches.

If baby's health begins to fail and its parents know who has praised its beauty, they must find that person. Putting the child in his or her arms, they compel the blunderer to annul the effects of the bewitchment by a blessing or by spitting on it. ${ }^{230}$ If the admirer is more inclined to superstition than to the use of the pious phrase, he can himself make the protective sign of the horns at the time he eulogizes and all will then be well. Moreover, the nurse 
or the mother of the baby, as the case may be, has always at her command a quick and drastic remedy. She need only spit in the direction of the danger or directly on the child, and preferably three times and as forcibly as possible. ${ }^{231}$ If a woman of questionable character has kissed a newborn baby, somebody ought to save it from any evil which this act of affection might cause, by spitting, even were it only once, behind the kisser. ${ }^{232}$

The situation seems to have been much the same two thousand years ago. There would be many occasions in the early life of man when spitting would be the quickest form of counter magic to use. As a gesture of contempt, hostility, and insult, it should put a stop to any attack. So we learn that if a person gazed upon a sleeping infant, or a stranger entered the room who might be dangerous in some magic way, a right-minded and prudent nurse would spit thrice in the direction of her charge. ${ }^{233}$

Even such a parental pleasure as keeping track of a child's growth by measuring and weighing is an indulgence fraught with peril of an occult character which derives, in its ultimate analysis, from the emotion of envy. Anybody who knows just how great or how numerous a person's blessings are is able, out of jealousy, to lay a spell on him or work some other form of sorcery to end the good fortune. To bewitch or injure someone magically with the tongue's speech was in Latin fascinare lingua. You could do it, for example, as we learn from lovelorn Catullus, if you knew just how many multitudinous kisses a woman bestowed upon her lover. ${ }^{234}$ The superstition about exact numbering and other beliefs akin to it continue to be current in Latin countries. ${ }^{235}$ And so an Italian father may have the good sense to realize that if he remains ignorant of exactly how much his incomparable youngster is breaking records of growth for his age, he is less likely to indulge in thoughtless boasting and so unwittingly to draw the attention of a baleful eye of envy which can stunt the baby's increase. ${ }^{236}$

In order to meet the threats of an evil eye and in general to annul the maleficence of magic, boys and girls in Roman times used to wear, suspended from the neck, the bulla, a sort of locket or spherical pendant. This contained an amulet (most frequently the figure of a membrum virile, such as Italian babies may still wear), and might be inscribed with its owner's names. Amulets seem to have been deemed most effective when they were obscene, 
grotesque, or terrifying: they compelled the attention of that menacing glance.

Other charms besides the locket might be hung from the neck or worn elsewhere on the person. Sometimes natural objects were put to this prophylactic use. Among those that might protect a baby were the notably large horns of the stag-beetle. ${ }^{237}$ The amuletic use of insects is by no means an outmoded practice among uneducated Sicilians even now. ${ }^{238}$

In Roman antiquity nurses would put a bit of garlic, Allium sativum, in the swaddling-clothes of their little charges. It was considered to be an effective avertive for keeping out of the house the vampirical creatures who molested children: the hawthorn that was planted in the window might have let some of them slip by! Merely eating three cloves of garlic every morning would keep evil spirits from entering your body, but that regimen might be difficult even for an Italian baby to follow. ${ }^{239}$ There were also Romans who believed that the skin and tooth of a wolf would protect the helpless young. ${ }^{240}$ One might imagine that this superstition went back to the days when a wandering wolf served as godmother to Romulus and Remus. Then there were charms that were manufactured to represent various magically protective plants and animals. These were made with varying degrees of artistry out of metal or other material. Gold in itself, no matter in what form it might be employed to adorn the baby, would reduce, the Romans thought, any harm which sorceries could work. ${ }^{241}$

In modern Italy and its adjacent islands there are superstitious people who will not place their full dependence for baby's wellbeing upon the rites of baptism and the supervision of Christian powers. While a representation of the Madonna with her own Bambino looks down upon the sleeping child, and tiny bags containing relics of the saints are tied to the bars of the crib, ${ }^{242}$ and the family keeps close by a small container of holy water which was blessed on Palm Sunday, timorous, superstitious Italians are prone to supplement all this religious or semi-religious provision by amuletic objects and occult agencies which they believe will work against disease, magic, or the spirits of evil that are ever besetting the young and helpless. We may, indeed, discover a quaint admixture of what passes for Christianity and what, if truly named, is nothing but heathen superstition. Thus, south Italians, if they 
are true sons and daughters of trusting ancestors in the days of paganism, will hang from baby's neck, attached to a circlet, a tiny bell, a bronze or gold medal of the Virgin Mary, or a scapulary, a little packet of cloth or leather which contains the name or a tiny likeness of the Madonna, their Madonnina. ${ }^{243}$ The packets are called abitini, devozioni, etc. ${ }^{244}$

The amulets that are not in sight on the child's neck or attached to his arm or wrist ${ }^{245}$ may be hidden in his swaddling-band: ${ }^{246}$ such things as the claw of some animal, amber, and witch stones..$^{247}$ There, too, the mother may put a bit of bread and salt, and a piece of the lumen Christi, a wax candle, which got its special powers during the religious functions of Holy Week. ${ }^{248}$

Some mothers put their trust in a tiny bag of magic herbs which an expert in witchcraft bids them place under baby's pillow. Pennyroyal, rue, wild marjoram, wormwood, and Johnsroot may be the choice, ${ }^{249}$ but anywhere on his person such powerful avertives as garlic, leeks, and the erva cacciadiavuli, the herb that chases out the devils, ${ }^{250}$ should do the business. The bed itself must have its magic protection..$^{251}$

Among the semi-magical and semi-religious safeguards which Sicilians may use is the abbizze, or, as we might translate it, the $A B C$, a tract which gets its name from the fact that it contains portions of the alphabet. Scholars have pointed out that the use of these, as also the use of letters of the alphabet traced by the bishop with his pastoral staff in a bed of ashes at the consecration of a cathedral, may be somewhat analogous to the employment of letters on certain tablets which were consecrated to Rehtia, an ancient goddess of the Veneti. ${ }^{252}$

In order to protect the infant from sorcery between its birth and the saving day of baptism, that brief period of special peril, it is advisable to put scissors behind the entrance door and two knives, crossing each other, between the mattresses on which he sleeps. ${ }^{253}$ Some seek to ward off the influence of the Evil Eye by putting behind the door mattocks, cattle horns, or horseshoes. ${ }^{254}$

However brief and sketchy, the account which we have just given of ancient and modern beliefs in magic and other superstition so far as they are pertinent to the life of a baby, may be of some help as a background to what we now have to say about the doctoring of young children in the widely separated periods with which 
we are concerned. It is hardly necessary to remark that we are not going to be much engaged with the remedies and therapeutics of scientific pediatricians. Our concern will be with Italian folkmedicine of the traditional sort. Very commonly, this has elements of magic in it which commend it in families where the ways of thought and much of the daily life are primitive. Among such people any diagnosis of disease must constantly include the possibility that a witch or sorcerer has been at work. It is, indeed, hard to say whether lovers or ailing children are believed to fare worse at the hands of such beldames and impostors.

Italy is not the only enlightened country in this world of modern science where there are people who, when doctoring a baby, put more trust in some ignorant but shrewd old woman of their community than in any physician. ${ }^{255}$ They have more faith in her powers to nullify sorcery than in the prayers and exorcisms of the parish priest. The local wise woman and practitioner in irregular medicine, the medichessa, not only sells drugs of secret composition and concocts fomentations of magic herbs, but uses mystic speech. She can utter compelling incantations..$^{256}$ She is easier to confide in than the state or commune doctor, who at any time may interfere with his newfangled notions about sanitation and hygiene which upset both human and animal life in the household. What is more, they think that the maleficence of a witch or the influence of an evil eye may be more responsible for baby's marasmus than any malnutrition or dietary deficiency that a doctor dwells on. ${ }^{257}$ It is witches also who keep the baby restless. ${ }^{258}$ They are eager to suck its untainted blood. Peasants who cherish such ideas as these are not going to resort to the regular physicians who serve the wellto-do and educated people of the town. They have access to lore which may go back through generations of their ancestors, aye, back even to their remote Roman forbears.

The time when a child cuts its first teeth has always been a period of maternal anxiety and of domestic insomnia. The ancients had various superstitions about it. When we read how malominous many Italians of our age consider it to be if a baby comes into the world with teeth already cut, ${ }^{259}$ we note with interest the cases in antiquity when this premature equipment did not prevent the "toothed" (dentatus) baby, or, at any rate, those who continued his name Dentatus from growing up to high distinction. 
The careers of those outstanding citizens Manius Curius Dentatus and Lucius Siccius Dentatus may serve as sufficient evidence. ${ }^{260}$ On the other hand, the Romans thought that when a girl baby was born possessed of a full array of teeth, it meant destruction to any community to which she might be taken. ${ }^{261}$

Those of my readers who are familiar with Florence and Verona know that in the neighborhood of those two cities the best orrisroot has been grown for the manufacture of perfumery. ${ }^{262}$ In old Roman days one might see the dried root of this plant suspended from the neck of children for them to bite on during their teething. Similarly today, a finger of orris-root provides baby with a favorite dentaruolo. ${ }^{263}$ For the same purpose, however, he may have various amuletic objects dangling from a necklace. These should ease the discomfort of his tender gums as well as keep him safe against the Evil Eye and against any maleficence of witchcraft. In Roman times the first teeth shed by a colt were particularly prized for baby's chewing: ${ }^{264}$ they were not merely a physical comforter but had occult value. Other amuletic aids in dentition were gritlike substances from the horns of snails, ${ }^{265}$ vipers' brains, ${ }^{266}$ the largest teeth of serpents, ${ }^{266}$ a stone extracted from the head of a boa, ${ }^{267}$ or its brains, ${ }^{268}$ a tiny stone or bone said to be found in the head of a slug, ${ }^{268}$ and the tooth of a wolf. ${ }^{269}$ The latter had the additional occult merit of keeping him, the Romans believed, free from frights. A wolf had once done much for the Latin race by suckling the twin foundlings Romulus and Remus: it might be expected, therefore, according to the reasoning of an ancient nurse, to continue service to the children of Rome even after their suckling period. The dolphin was another creature that figured prominently in ancient folklore, but I see no special reasons why the ashes that resulted from burning its teeth, when mixed with honey, should make a good fricative for baby's gums. Touching them with a tooth of this fish is also recommended.270

We may feel certain that the ancients would have found nothing unreasonable about a current Italian belief that in order to insure a child a fine array of teeth in a powerful jaw, it is well to suspend from his neck any teeth from such strong-jawed animals as the wild boar, wolf, fox, dog, and bear. Such are common amulets. ${ }^{271}$ In order to speed up his teething, baby's gums are rubbed with the brains of a hare, possibly, as Zeno Zanetti suggests, because that 
animal's proverbial swiftness is thought to affect in some occult way the coming through of the first teeth. ${ }^{272}$ Once a person begins to think in terms of sympathetic magic, all things appear to be possible. In any case, the Romans had already set the precedent for using them in dentition as also the brains of pigs and sheep, and the milk of goats. Yet these are animals which, one might fancy, were not likely to speed up anything. ${ }^{273}$

As a fricative to ease dentition the Italians may now employ a tooth of a wild boar, fox, dog, or bear, or an ancient tooth from another child, or even a piece of amber, as well as also those various amulets that baby could use "on his own" as suspended from his neck..$^{274}$ If one would bring in the second set of teeth "as strong as a wall", the first, as they come out, should be put away carefully in a crack of some wall. ${ }^{275}$

The teachings neither of church nor of science can dissuade many members of the lower classes in Italy from accrediting to certain objects which to an imaginative person can suggest in some way the organs of sex a special magic potency. Cowries, i.e., shells of the Cyprea species, and cockles bear enough resemblance to the female pudenda to give them a mystic value. ${ }^{276} \quad$ Faith in them as amuletic charms was in evidence, we believe, as far back in the history of man as the Iron Age. ${ }^{277}$ Sicilians will put together a necklace of them for a teething baby. ${ }^{278}$ The shells appeared among the baubles of necklaces in classical times, and figured, no doubt, as a prophylactic against evils of a magic nature and at the same time as a smooth, round object just suited to ease a baby's teething.

Next to dentition the invasion of parasitical worms is supposed to upset otherwise healthy Italian babies as much as any other ordinary ailment. ${ }^{279}$ The use of certain remedies has been traditional during thousands of years. The vermifuges interest us most when something magical or supernatural can be detected in their use. Our earliest Latin reference to them seems to be in the $D e$ Agricultura of Cato, the Censor, whose long life covered the years from 234 to 149 B.C. Already in his time the pomegranate tree provided anthelmintics. It still does in Italy. ${ }^{280}$ Wormwood also has a long history behind it in that character. ${ }^{281}$ Authorities in pharmacology note that derivatives from either pomegranate or wormwood may prove to be rather drastic remedies. Garlic ${ }^{282}$ and 
onions are now a milder recourse when an Italian has to rid his child of worms. The former when it has been pounded up with mint and moistened with vinegar serves as an anthelmintic plaster. The mere odor is said to drive the parasites from their feedinggrounds, although these, according to rustic teaching, extend all the way from mouth to anus. ${ }^{283}$ A double protection for the Italian child is to wear as amulets the vertebrae of a snake which ants have bared of its flesh, and a necklace of the odoriferous vegetable. ${ }^{284}$

One prescription which Pliny offers may be said to take pity on little children: according to him, lupines will work as a vermifuge if merely applied externally to the abdomen. ${ }^{285}$ Rue was recognized as a good one two millennia ago, as it still is. ${ }^{286}$ In this case, too, even the mere odor is said to dislodge the parasites. ${ }^{287}$ Some Italians trust to it, even when it is simply put on the belly or on the soles of the baby's feet. ${ }^{288}$ In the province of Basilicata, the worms receive a quite absent treatment from the herb: it is merely put under the pillow. ${ }^{289}$ Such methods ought to win favor for any pediatrician with his young patients, if they will only work. Almost as inoffensive is the application to the victim's nose, temples, and throat of certain unguents which aged experts in the use of folkmedicine recommend. ${ }^{290}$ We seem to be wholly in the province of the occult when we read of a rustic remedy of Perugia which requires anointing the navel of the suffering baby with hot oil in which the dung of a pig has been dissolved. ${ }^{291}$

Amuletic charms for use against the parasites are in favor with some mothers. Here, as in dealing with the troubles of teething, cowrie shells may be a Sicilian choice, along with a tiny imperforate key of silver, in other words a male key. ${ }^{292}$ Then there are the witch-stones to use not only against a baby's worms but against the threats of sorcery of any sort. These pietre stregonie may be fossil corals which display in their structure the appearance of tiny stars and so bear the specific name of pietre stellarie. ${ }^{293}$ Calabrians, women as well as children, will sometimes be found to be wearing fossil shark's teeth concealed in tiny bags beneath the shirt. Such "tongues of stone", lingue di pietra, or "tongues of S. Paul", lingue di S. Paolo, ${ }^{294}$ are, no doubt, the glossopetrae to which Pliny refers. ${ }^{295}$ Baby has one to bite on when he is teething. As an amulet it is expected to protect him against intestinal worms and also against all injuries that can come from the Evil Eye. ${ }^{296}$ 
It is quite natural for a certain type of mother to associate some Christian procedure with the various superstitions of a magical sort. In order to rid her baby of its worms, she may put it across her knees and murmur in its ears an incantation. Then she blesses it with the sign of the cross and so makes doubly sure of their exit. $^{297}$ She thinks that merely marking her child's belly with a cross in ink should work the same result. ${ }^{298}$ Who will decide whether it is a medical or a magical remedy in the thought of a woman of Perugia when she takes an ascarid that her baby has spued from its mouth, mashes it up, and administers it in the child's pap or in some water which contains powdered egg-shells? Swallowing this should make the child emit more of its worms-a sort of homoeopathic process, she may suppose. ${ }^{299}$

There is a curious Italian superstition that one of the causes of worms is the emotion of terror. ${ }^{300}$ For this reason an Abruzzese mother will not bring her swaddled infant in front of a mirror, lest it take fright and so become infested with parasites. ${ }^{301}$ Kissing the child on the forehead is said to bring worms into its intestines, but you can prevent it, we are told, by merely saying Crisce cappomonde..$^{301}$

We may next turn to some of the other troubles besides cutting teeth and playing host to intestinal and stomachic parasites which vex the opening years of life. Again we shall consider not what the reputable Italian pediatrician would prescribe for them but rather certain remedies that are to be found in use among uneducated people. Their superstitious ideas can often make them seem like old Romans who have suddenly come to life again to deal with the latest generation of their descendants. We may work down (or up, whichever my reader may decide the process is) from some that are more purely medical to those that are partly or wholly of an occult or magical nature.

In sufficiently backward communities a suckling who is suffering from the disease called sprue or thrush may have the head of a frog put in its mouth, ${ }^{302}$ and a child who regurgitates its milk has the tail of a live tench inserted there. ${ }^{303}$ Oral ulcerations may lead an ignoramus of Umbertide to swab off the victim's tongue and clean his mouth with the end of a cat's tail. ${ }^{304}$ An easy cure for such ailments is to have a shepherd, malodorous from his sheepskin garments and the care of animals, merely kiss the baby, or spit in 
its mouth..$^{305}$ Such a pastoral doctor would, no doubt, sometimes get his fee "in kind" and not like it.

Sometimes we can relate a modern outrage to therapy or decency with an ancient. The powder of calcined oyster shells mixed with stale wine made a sort of salve that a Roman baby might have smeared on a skin eruption or on running ulcers. ${ }^{306}$ It may be at least harmless to wash a child today in a decoction of rue to keep off any evil from witchcraft, but what shall we say of the practice of washing it in wine to make it robust? ${ }^{307}$ There are ignorant women dwelling in the region of Perugia, and probably in other places, who not only change their baby's garments infrequently in the belief that its combined excretions will insure its growing up with a soft, white skin, but themselves use the child's urine as a cosmetic face-wash. ${ }^{308}$

Knowing, as I do, that a remedy which seems to be in vogue in all parts of Italy for curing a child of his habit of wetting the bed is to feed him a mouse without his knowing what he eats, ${ }^{309} \mathrm{I}$ am not surprised to find that boiled mice were already recommended for this incontinence nineteen centuries ago. ${ }^{310}$ In fact, the alimentary canal of Egyptian children, mummified ages earlier, has revealed the remains of mice which were unquestionably taken as medicine. Pliny recommends them for numerous ailments. Administered roasted, they would stop a child from dribbling at the mouth. That we may well believe.

When a baby arrives in the world weak and near suffocation, the mother of it may be advised in some parts of Italy to cut the throat of a black hen and clap the animal, still palpitating, on the hind parts of the child, col becco infisso nell' ano. If my reader knows the Italian word for beak, he can shock his sense of delicacy by translating the rest with no help from me. The hen is supposed to swell up, correcting the baby's condition by drawing out the causes of it. ${ }^{311}$ The very color of the bird, an essential specification, suggests that we have here a bit of the black art in operation, and not merely a new sort of poultice that is credited with an unusual drawing power. The method used is merely a modern exemplification of a common procedure in antiquity by which a disease is transmitted from an ailing person to some animal victim which thereupon suffers a vicarious death. When, for example, the Roman applied to the abdomen of someone who was afficted 
with pain in that region a live duck and a lap-dog of the Melitaean species, or a puppy that was not yet old enough to see, a postmortem examination of the animal was expected to reveal in it the very malady of which the beneficiary had been relieved. ${ }^{312}$ As a matter of fact, that anal extraction of disease is actually used today on Sicilian babies when they are suffering from the colic. ${ }^{313}$ But for this common ailment there is also available a remedy which has none of the offensiveness of these animal transfers: simply have a twin touch the belly of the little sufferer with his foot. ${ }^{314}$

Convulsions are another dreaded ailment, but why let an infant have them? As soon as it is born, a tortoise should be killed and a few drops of its blood should be given it to drink. ${ }^{315}$ Such a quiet animal ought to be potent. There is a well-known quietus for an epileptic fit, a small iron key, la chiave di San Valentino. Suspended from a baby's neck, it is thought to prevent and cure this affliction. But in order to stop the paroxysms of a child the key must be one that is made of brass or silver. ${ }^{316}$ If, in spite of its wearing a protective key, Papal coin, or the dried heart of a cocksparrow suspended from its neck and a black silk handkerchief tied around it, it does have fits, hot wax dropped on its neck and finger nails from a candle which has had an ecclesiastical blessing may be expected to work a cure. ${ }^{317}$ The heart of a swallow which has been dried is used as an amuletic protection against a recurrence of such troubles. ${ }^{318}$

In order to prevent an infant from suffocating itself during sleep, one need only put on it somewhere an emerald. We must suppose, however, that few Italian parents could possess such a costly means of insurance. ${ }^{319}$ Another charm that is favored for a baby is a gathering of badger's hair. ${ }^{320}$ Like hair from a red dog, if it is suspended from the neck, it should keep him from becoming pale, weak, and emaciated. ${ }^{321}$ The long-suffering toad has to provide another charm. At the time of a new moon all four of its legs are cut off while the reptile is still alive, so that, when suspended from a child's neck, they may cure it of scrofulous ulcerations. ${ }^{322}$

It is Pliny the Elder who tells us that, if babies are restless, the dung of goats should be attached to them in a piece of cloth. This acts as a sedative more effectively on a girl than on a boy. ${ }^{323} \mathrm{He}$ tells us, too, that we can make the little ones fearless by putting on them the skin of a wolf, or of an ass, or a piece of it which has the 
hair on. ${ }^{324}$ We can prevent their alarms by attaching to them the tooth of a wolf, ${ }^{325}$ a dolphin, or a dogfish. ${ }^{326}$ Such notions are not unknown in Italy now. Italian babies still suffer terribly from "night terror", pavor nocturnus, and the less usual fits of fright that may come by day, pavor diurnus. Zeno Zanetti reports out of his profound knowledge of the folklore of Perugia that a child may be safeguarded against terrifying nightmares by giving it doses of the brains of a she-goat, if local teaching is followed, while as an amulet it may still, as in antiquity, wear a piece of the skin of an ass. ${ }^{327}$ In this connection we remember a prescription from the magi both for the diseases which belong particularly to infancy and for epilepsy. It requires one to give the youngster the brains of a she-goat. But they must be passed through a gold ring and dropped into the mouth before the child is given its milk. ${ }^{325} \mathrm{Su}-$ perstitious Neapolitans maintain that a remedy for fear is the eating of scarab beetles. ${ }^{328}$ But there are Bolognese mothers who fortify the infant against fear by washing it with water in which certain herbs have been boiled. ${ }^{329}$ In the Abruzzi country you will be told not to put any sort of necklace on a baby boy lest he grow up timid. ${ }^{330}$

Exposure to the hot sun of Italy might give the Roman baby siriasis, an inflammation of the brain. ${ }^{331}$ In some Latin references, perhaps, the word should be translated "sunstroke." In any case, its derivation reminds us that Sirius, the Dog-Star, must be held responsible for a period in midsummer when Helios, the Sun-God, is likely to do his worst. We cannot be much surprised, then, if the heliotrope, Heliotropium europaeum (also called verrucaria, a "wart plant" which should cure those excrescences), provides leaves, which, when prepared in the form of an ointment, were deemed a remedy for the disease. A turnsole ought to cure an infant that had been turned too much towards the sun. It was also supposed to be good for the child's convulsions, even if they were of epileptic origin. If this plant was not available as a remedy, one had merely to find dog dung that contained bones and then attach these to the baby as an amulet. ${ }^{332}$ Also conducive to a cure was a sponge wet with cold water, or a frog applied, bellyside in, on the suffering head. ${ }^{333}$

Babies were exposed to much other therapy that they might live to regret. Their precious eyes might be smeared with the slimy 
fluid from snails to straighten their lashes and make them grow. ${ }^{334}$ Instead of cough medicine, they might have to depend upon a charm attached to their person, such as raven's dung in a piece of wool. $^{335}$ On their ears, when diseased, went goose-grease with the juice of basil. ${ }^{336}$ If food stuck in baby's throat, letting certain rough, hairy worms crawl on its neck might loosen the obstacle, presumably through the child's reaction of terror. ${ }^{336}$ A foolish parent might decide that in order to safeguard an infant against. epilepsy and various diseases that threaten the first years of life it was worth while trying a prescription found in the Natural History of Pliny: daily for forty days drop a liquid compound of the liver of an ass with panax or all-heal into its mouth. ${ }^{337}$ If the child suffered pain in the spleen, they treated it topically with a preparation of honey and the milt of an ox. This was recommended also as an application for running ulcers. ${ }^{337}$ If ulcers were forming in baby's mouth it was the milt of a calf boiled in wine that provided an ointment for them. ${ }^{338}$ The way to stop the child's diarrhoea was to apply a hare's rennet to the breasts of its nurse. ${ }^{339}$

Even the healthiest children are exposed to various ills from sources of which one is unlikely to think. Anybody who understands the power of sympathetic magic will realize why it is that some Italian mothers when washing their child's diapers take pains not to beat them too hard against the stones of the fountain lest it cause the wearer the gripes. ${ }^{340}$ Mothers are cautioned particularly not to let their little ones nap in the shade of a walnut tree; for such serve as the sabbath dormitory of the witches and they are likely to anoint a child with magic stuff and so make it pale and subject to rickets. ${ }^{341}$ The great assembly of witches is on the night of S. Simone in November. Their most celebrated meetingplace was under a walnut tree at Benevento. According to some reports, this was destroyed centuries ago, but they continue to use the site for their rendezvous. There one may see them dancing on the night of San Giovanni Battista. ${ }^{342}$ I have not had that good luck.

Even within the field of surgery magic had its role to play in Roman times, and it still does among the modern people of Italy in sporadic instances. Among the worthies of early history there is no more respectable figure than Cato the Elder, nor can he be classed among the unintelligent of his time. ${ }^{343}$ Yet when anybody 
was suffering from a dislocated bone such as children are so likely to get, it was Cato who would have two men apply to it a split green reed, while a powerful spell was recited over it. The words of this sound less like Latin than like some formula which children might use in a counting-out for a game: motas vaeta daries dardarese astataries dissunapiter. You almost expect to hear at the end the decision "You are it." After joining the ends of the split reed around his thighs, one could expect the bone and joint to unite properly. ${ }^{344}$ In our age an Italian who is possessed of the same degree of faith as Cato passes a baby afflicted with a rupture above a cleft made in the fork of an oak or an elm. He believes that the eventual union of the severed wood, which has to be bound with a sheathing of the tree's own bark, will effect a similar healing of the child. This was orthodox treatment as long ago as the days of Marcellus Empiricus of Bordeaux. ${ }^{345}$

A cure for what was probably hydrocele, and not a rupture (as so often translated), which also depended upon an operation of magic, was to let a green lizard bite the baby while it lay asleep, then attach the reptile to a reed and hang it in the smoke of a fire until it died. By that time the child was supposed to be perfectly cured. ${ }^{346}$ The masters of medical hocus pocus sought to make this more impressive by certain details in an alternative. A male lizard should be the choice. It must bite the part afflicted through stuff of gold or silver, or of purple. Then, fastened in a cup that had never been used, it should be given the smoking. ${ }^{347}$ If these methods failed, one could try burning snails and applying the ashes from them, mixed with frankincense and the juice of white grapes. When this had been done for a period of thirty consecutive days, the infant ought to be quite sound..$^{348}$

But an Italian has at his command for the protection of his children magic preventives not only of disease but even of accidents, if what I read be true. What could be simpler, for instance, than to keep a little boy from falls by having him suck the first egg gathered from the hencoop in the morning? Another magic protection is to wear a turquoise. If the child does, however, have a bad fall on his head, some shelled beans put on his forehead is a remedy widely known in folkmedicine for his pain as well as for headaches in general. ${ }^{349}$

In this little treatise on the birth and infancy of children in Italy 
at two widely separated periods of that country's history I have correlated with our ancient data some of the information which I have gathered during years of acquaintance with many parts of the Italian peninsula and Sicily and from a lifetime of reading in the voluminous literature which has been written in various languages about their inhabitants. I have written as a lover of the Italian land and people, but I have written inevitably as a fallible alien who realizes that even as a well-wisher who is determined to be as free from bias as possible, he will need charitable judgment from critics who have seen things with different eyes, heard things with different ears, and interpreted what they have seen and heard from a different point of view. So far as antiquity is concerned, my account was bound to be at least somewhat uneven, because that ever churlish fellow, Father Time, has allowed to survive in Latin literature such disparate amounts of information about the different topics which we have treated. No doubt I have offended the spirits of the dead more often than the feelings of the living. But of ghosts I have no dread, not even of that of "imperious Caesar, dead and turned to clay." In fairness, however, to Italy my readers must also remember that my modern analogies and apparent survivals have been found, as a rule, in the life of the less favored classes of the community. Lack of education makes the proletariat of any country cling to traditional beliefs and habits; poverty compels them to follow primitive ways of life..$^{350}$ Among people too poor to travel much beyond their own town or village, campanilismo, "church-steeple-ism", is an enduring characteristic that makes them wary of anything that is foreign to the community where they live.

We have dealt rather fully with superstitious beliefs and practices which affected and are still affecting the well-being of mother and child, because neither classical scholars nor writers on modern Italian life seem to have had much knowledge of such matters. Since no man can know the extent to which the prescriptions and directions of doctor, quack, or witch were actually followed by the ancients, our repetition of them may appear, at first thought, to be of minor importance, no matter how entertaining they happen to be. But when we find that so much of the nonsense survives among those who may be called the descendants and intellectual heirs of the old Romans, it must concern anybody who is interested 
in studying human culture and the forms in which it has been transmitted from age to age. Moreover, it is obvious that in such a relatively poor country as Italy has long been and must now, we fear, long continue to be, legitimate medicine fails to provide adequately for the needs of an enormous number of people. Even among the more prosperous citizens a doctor may lack such intimacy with a family under his charge as would acquaint him with much that his patients may do when he is not around to outrage science and even the dictates of common sense. My study of folklore leads me to believe that medical practitioners everywhere have this handicap to a greater degree than such busy men can fully realize. While I have put in my notes only a few references to English and American parallels, I commend them particularly to any physician who may read this book. Familiarity with such lore will convince him that there are superstitions which have shown a tenacity of life that almost justifies our terming them immortal, and which have a power to harm that makes them something more than negligible absurdities for his profession.

We may well believe that reproduction in human beings is still physically quite what it was when Cain and Abel were begotten, carried, and then delivered, the first of earth's children, according to our Biblical account, but what Adam and Eve did to their sons during gestation and infancy has perhaps never been precisely duplicated by any parents within these last two thousand years. Nature no longer has her primeval way with the beginnings of man. Man interferes in countless particulars. If, however, baby Caesar, baby Vergil, or baby Pliny, not to mention any babies of the then less favored sex, were introduced among a score of children of the same age in an Italian nursery, I am sure that identification tags would be necessary to differentiate them from the rest. It is pleasant to think, too, that during their opening years of life they would all play happily together, having none of the thoughts of their stupid elders about race, color, creed, or social origin to disturb their peace or prospects. Yes, it is what these elders would think and do, sensible and nonsensical, that would so greatly affect their start in life, whether they were to exist and die in the slums, unknown to fame and fortune, or were to grow up a Caesar or Vergil, a Mussolini or D'Annunzio. That "chance makes our parents" can still be man's worst mischance. 


\section{NOTES}

1 Notable among many references is Ovid, $N u x, 23-24$; cf. in Pliny $N$. $H$. (hereafter abbreviated $N . H$. with the numbers) $21.116 ; 24.18 ; 25.25 ; 28.81$; 29.85 ; 30.142; Gell. 12.1.8-9. It is clear that the gullibility of man had no limits when he was trying to circumvent Nature. The subject deserves more thorough investigation than it has yet received. See, however, A. G. Roper, Ancient Eugenics, which this writer reviewed in The Classical Weekly, VIII (1915), 202-207. We may cite also Palmer Findley, Priests of Lucina, The Story of Obstetrics, 44, where he deals with Soranus.

2 Dig. 47.11.4; 48.8.8; for the death penalty cf. Cic. Pro Cluent. 11.32; Dig. 48.19.39; Paul. Sent. 5.23.14.

${ }^{3}$ For the attitude of Mussolini see E. Ludwig, Talks with Mussolini, 168-171; cf. C. M. Hamilton, Modern Italy, 88-89; 196-197; F. Fox, Italy of Today, 113; 219-222.

${ }^{4}$ Cf., e.g., P. Sébillot, Le paganisme contemporain chez les peuples celto-latins, 15; M. Pasquarelli, "Medicina popolare basilicatese", Archivio per lo studio delle tradizioni popolari (hereafter Archivio), XVI (1897), 52. On prolongation of nursing with intent to prevent pregnancy: P. H. Williams, South Italian Folkways in Europe and America, 89.

5 See, e.g., Z. Zanetti, La medicina delle nostre donne, studio folklorico (hereafter abbrev. La medicina), 116; 118; 185; M. Pasquarelli, op. cit. (see note 4) XVI, 52-53; G. Finamore, Tradizioni popolari abruzzesi, 60; 118-119; cf. for Ruta graveolens, N.H. 20.143; for asplenium: 27.34; and for a use of savin: 24 . 102.

${ }^{6}$ Cf. G. Ferraro, "Botanica popolare di Carpeneto D'Acqui", Archivio, IV (1885), 176 with N.H. 27.78 and 80. Among some Italians asparagus has a similar reputation: C. Coronedi-Berti, "Appunti di medicina popolare bolognese", Rivista di letteratura popolare, I (1877), 4.

${ }^{7}$ E. Canziani, Abruzzese Folklore, 213.

$8 \mathrm{Z}$. Zanetti, La medicina, 118; on objects introduced into the womb cf. loc. cit.

${ }^{9} \mathrm{Z}$. Zanetti, op. cit., 105; 252. 9a Among the most dreaded portents of some evil coming to the nation was the birth of young to a mula. Cf., e.g., Jul. Obs. Prod. 37; 55; 88; 130. Cicero commented interestingly on this unnatural fecundity: $D e$ Div. 2.22.49.

${ }^{10}$ The classicist will not overlook the highly interesting chapters in Gellius, 3.16, and Pliny the Elder, N.H. 7.38-40. ${ }^{11}$ See, e.g., N.H. 7.47. ${ }_{12}$ Cf., e.g., Liv. 27.37.5-6; 31.12.6-8; N.H. 7.30; 7.34-35; 11.262; Val. Max. 1.6; 6.5; Jul. Obseq. Prod. 38; 46; 51; 66; 73; 84;86;94;96;100;107; 108; 110; 113. ${ }_{13}$ Cf. N.H. 7.36; Jul. Obseq. Prod. 31; 34; Gell. 9.4.14-15 ; Auson. Epigr. 76; Phlegon Trall. De Mirabilibus, 4-9. $\quad{ }^{14}$ Cf. N.H. 7.33-34; Jul. Obseq. Prod. 73; Gell. 10.2. $\quad 15$ N.H. 28.97. $\quad 16$ N.H. 30.125. ${ }^{17}$ N.H. 30.130. ${ }^{18}$ N.H. 30.131. 19 N.H. 30.142 .

${ }^{20}$ Catullus 64.377-378; cf. C. T. Ramage, The Nooks and Byways of Italy. Wanderings in Search of its Ancient Remains and Modern Superstitions, 208. Comparable also here is the Italian test of either male or female virginity: Notes and Queries, Ser. 3, XII (1867), 475-476. For ancient tests of virginity 
see, e.g., Prop. 4.8.3-14; Ovid Fast. 4.323-325; Plin. N.H. 7.120; 28.12; Val. Max. 8.1.

21 N.H. 36.142 and note 63 in the Translation of Pliny by Bostock and Riley, VI, 361; Apul. Apol. 45; 48. We are reminded of the Biblical trial by ordeal: Numbers 5.11-31, the Roman test at Lanuvium (Prop. 4.8.3-14), not to mention others.

${ }^{22} \mathrm{R}$. Corso (Reviviscenze, studi di tradizioni popolari italiane, 25) cites the case of Macrina, wife of the consul Torquatus. Cf. P. H. Williams, op. cit. (see note 4), 87; S. La Sorsa, Costumi e riti pugliesi, 3. The belief is so widespread in our country that it figures among the fatuities noted by Morris Fishbein, Shattering Health Superstitions, 72-79. On its inacceptability see, e.g., J. Morris Slemons, The Prospective $M o t h e r^{3}$, 86; and, in general, on prenatal influences Joseph Garland, The Youngest of the Family, 14; F. C. Irving, The Expectant Mother's Handbook, 196-197.

${ }^{23}$ Messina e dintorni, guida a cura del municipio (1902), 92; Z. Zanetti, La medicina, 110; Nonne e bambini, saggio di credenze popolari umbre, (hereafter abbrev. Nonne) 28-29; G. Finamore, op. cit. (see note 5), 59; 60; G. B. Corsi, "Usi natalizi senesi", Archivio, XIII (1894), 474; S. La Sorsa, Costumi e riti pugliesi, 3; P. Ellero, Scritti minori. Delle superstizioni volgari in Triuli, 21; G. Pitrè, Medicina Popolare Siciliana, 67. Italians call the marks voglie, i.e., "wishes."

${ }^{24} \mathrm{Z}$. Zanetti, La medicina, 138. According to a Pennsylvania superstition, rubbing it with the hand of a corpse will make it disappear: E. M. Fogel, Beliefs and Superstitions of the Pennsylvania Germans, 296, no. 1567.

${ }^{25} \mathrm{Z}$. Zanetti, op. cit., 81; cf. 111 ; 117: cause of a miscarriage or death; 177: brings a sty to the eye. ${ }^{26}$ N.H. 7.43. For the stricter use of the terms "abortion", "miscarriage" and "premature labor" cf. J. Whitridge Williams, Obstetrics $^{6}$, 759. $\quad{ }^{27}$ N.H. 7.42; Gell. 3.16.24. $\quad{ }^{28}$ N.H. 32.8. $\quad{ }^{29}$ Cf. N.H. 21.12. ${ }^{30}$ H. N. Maugham, The Book of Italian Travel, 46; W. J. A. Stamer, Dolce Napoli, 8; C. De Brosses, Selection from the Letters of, Transl. of R. S. Gower, 230; Mrs. Piozzi, Glimpses of Italian Society in the 18th Century, 208209; H. I. Tuckerman, Isabel or Sicily, 51; W. W. Story, Roba di Roma, 212. 31 W. J. A. Stamer, Dolce Napoli, $8 . \quad 32$ W. W. Story, op. cit., 501 ; cf. 505-506. During pregnancy a woman may develop an appetite for strange or unwonted food: cf. Albert Westland, The Wife and Mother, 13.

${ }^{33}$ N.H. 28.98. $\quad{ }^{34}$ N.H. 30.124. The ashes from burning an ibis are another suggestion: $30.142 . \quad{ }^{35}$ N.H. $10.32 ; 30.130$.

${ }^{36}$ N.H. $10.12 ; 30.130 ; 36.149-151$; Lucan 6.676.

${ }^{37}$ N.H. $37.154 ; 37.163 ; 37.180$. It is noteworthy that a piece of wood which has in it something that grew in it parasitically, e.g., mistletoe, is used today to prevent miscarriage from occurring among goats, sheep, and cows. It is only necessary to put it somewhere in their stable: Z. Zanetti, La medicina, 118.

${ }^{38} \mathrm{G}$. Bellucci, Il feticismo primitivo in Italia e le sue forme di adattamento, 92: una concrezione argillo-ferruginosa; cf. 36 : concrezione limonitica; see fig. 15a a steatite.

${ }^{39}$ N.H. 36.140. $\quad{ }^{40}$ Cf., e.g., N.H. 28.246: those found in the dung or in the uterus of hinds, used as an amulet. ${ }^{41}$ N.H. 30.130; 36.151. J. Mantegazza, 
"Di alcuni documenti che illustrano la superstizione in Italia e che si conservano nel museo psicologico di Firenze", Arch. per l'antropol., XXVII (1897), 483, no. 15.

42 N.H. 36.149.

43 N.H. 36.151 .

44 In another name for them, pietra aquilina, the adjective does not refer, as has been thought (C. Pigorini-Beri, "Le superstizioni e i pregiudizi delle marche appennine", Archivio per l'antropologia e la etnologia, XX (1890), 50), to a place where they are found, but it is to be connected with aquila, "eagle."

45 P. Mantegazza, op. cit. (see note 41), 483; Z. Zanetti, La medicina, 252; G. Bellucci, Catalogue descriptif d'une collection d'amulettes italiennes envoyée à l'exposition universelle de Paris, 1889, 48, tav. VIII, no. 10; 11; "Amuleti italiani antichi e contemporanei", Annali della facoltà di medicina e memorie della accademia medico-chirurgica di Perugia, XII (1900), 253, no: 13; E. Canziani, "Abruzzese Folklore", Folklore XXXIX (1928), 211. For their use in England during many centuries: Notes and Queries, Ser. 6, III (1881), 327 ; 510.

${ }^{46}$ Cf. E. Canziani, Abruzzese Folklore, 211; G. Pitrè, Medicina popolare siciliana, 451; Z. Zanetti, La medicina, 117; L. Marco, "Usi, costumi e credenze popolari di Mottola", Rivista delle tradizioni popolari italiane, I (1893-1894), 298. See further on the eagle-stone, C. J. S. Thompson, The Hand of Destiny, The Folklore and Superstitions of Everyday Life, 249. S. Seligmann, Die magischen Heil- und Schutzmittel aus der unbelebten Natur mit besonderer Berücksichtung der Mittel gegen den bösen Blick, 215-217; fig. 73a.

${ }^{47} \mathrm{Z}$. Zanetti, Nonne e bambini, 13: pietra aetite.

${ }^{48}$ G. Bellucci, Il feticismo (See op. cit. note 38) 93; 97.

49 N.H. 28.33.

50 S. Salomone-Marino, "Rimedj e formole contro la jettatura", Archivio, I (1882), 132.

51 Z. Zanetti, La medicina, $117 ; 252 . \quad 52$ N.H. 28.246. Amuletic also are the fish called echeneïs or echenais: $9.79 ; 32.6$; and a species of Libyan serpent, the amphisbaena, used either dead or alive: $30.128 . \quad{ }^{53}$ N.H. 28.247. ${ }_{54}^{54}$ N.H. 28.249-250.

55 N.H. 30.124 .

${ }^{56}$ Paul. Exc. 56.7 (Edit. of Lindsay 49.1).

${ }^{57}$ F. T. Elworthy, The Evil Eye, 353.

58 Z. Zanetti, La medicina, 251; G. Pitrè, Cartelli, pasquinate, canti, leggende, usi del popolo siciliano, 293; I. Nieri, "Superstizioni e pregiudizi lucchesi", Atti della reale accademia lucchese di scienze, lettere ed arti, XXXV (1919), 374 ; M. Pasquarelli, op. cit. (See note 4), XVI, 51; L. Di Pasquale, "Metereologia, medicina e superstizione popolare in Calabria”, Archivio XI (1892-1893), 249.

59 Z. Zanetti, La medicina, 142.

${ }^{60}$ G. Finamore, op. cit. (See note 5), 69.

${ }^{61}$ N.H. 30.129.

$62 \mathrm{Z}$. Zanetti, La medicina, 127. Upon the advisability of sexual congress at this time: op. cit., 123, note 3 . 
${ }^{63}$ N.H. 28.42. At a difficult childbirth the Italian husband may be called upon to go to the church belfry and pull the bell rope with his teeth: cf., e.g., G. Finamore, op. cit. (See note 5), 66.

${ }^{64}$ N:H. 28.59; cf. Ovid Met. 9.297-300. It may interest those who are curious about such things to know that crossing the legs is forbidden at a spiritistic seance: D. Rorie, Folklore, XLV (1933), 390-391.

65 Serv. Com. on Verg. Aen. 4.518.

${ }^{66} \mathrm{Z}$. Zanetti, La medicina, 112; 121 ; I. Nieri, op. cit. (see note 58), 354; A. De Nino, Usi e costumi abruzzesi, II, 20-21. Z. Zanetti (op. cit., 109; 112113) mentions many taboos that a pregnant woman should observe. According to Welsh superstition, the child would live to be hanged with a hempen rope: C. J. S. Thompson, The Hand of Destiny, 21-22.

${ }_{67} \mathrm{Z}$. Zanetti, La medicina, 121.

${ }^{68} \mathrm{Z}$. Zanetti, op. cit., 125.

${ }^{69}$ N.H. 30.129. $\quad{ }^{70}$ N.H. 32.6 (cf. note 52). ${ }^{71}$ N.H. 30.130. ${ }^{22}$ N.H. 28.251. ${ }^{73}$ N.H. 28.252-253.

${ }^{74} \mathrm{Z}$. Zanetti, La medicina, 257.

${ }^{75} \mathrm{G}$. Pitrè, op. cit. (see note 46), 449.

${ }^{76}$ Cf. Tert. Ad Nat. 2.11 ; Athen. 10.58 (442A).

${ }^{77}$ A. Karusio, "Pregiudizi popolari putignanesi (Bari)", Archivio per l'antropologia e la etnologia, XVII (1887), 320.

${ }^{78}$ G. Bacci, "Usi e costumi dei contadini della Valdelsa", Archivio XIV (1895), 219; A. De Nino, .op. cit. (see note 66), V, 107; S. La Sorsa, "Superstizioni, pregiudizi e credenze popolari pugliesi", Lares IV (1915), 59: before the image of S. Anna; also an oil lamp before that of the Madonna dei Sette Dolori: Z. Zanetti, La medicina, 122.

${ }^{79} \mathrm{G}$. Bacci, loc, cit. (see note 78).

${ }^{80}$ Tert. De Anim. 39. Minor deities to help were the Carmentes Postverta and Prorsa who were concerned with the birth of the baby in the proper position, the former with the head forward, an easy issue, the latter feet first, a difficult one: Gell. 16.16.

81 Serv. Com. on Verg. Aen. 10.76; Non. 528.

82 Paul. Exc. 77 (Edit. of Lindsay 67.25).

${ }^{83}$ A. De Nino, op. cit. (see note 66), V, 107; G. Finamore, op. cit. (see note 5), 63; S. La Sorsa, op. cit. (see note 78). They say that, if she is piqued, she may prolong the pains, quite as the ancients believed that their deities would do: Z. Zanetti, La medicina, 11.

${ }^{84} \mathrm{G}$. Bacci, loc. cit. (see note 78 ).

$85 \mathrm{Z}$. Zanetti, La medicina, 121.

${ }^{86} \mathrm{G}$. Pitrè, Usi natalizi, nuziali e funebri del popolo siciliano, II, 136-137.

${ }^{87}$ See esp. August. De Civ. Dei, 6.9; cf. Non. 528.11.

${ }^{88} \mathrm{I}$ believe that this is rightly so explained by F. Granger, The Worship of the Romans, 102-104.

${ }^{89}$ The most interesting passages are, perhaps, August. $\quad$ De Civ. Dei, $4.11 ; 4.21$.

90 G. Pitrè, op. cit. (see note 58), 282.

${ }^{91}$ Cf., e.g., G. Bacci, op. cit. (see note 78), XIV, 95 . For many minute precautions to be taken see M. Placucci, "Usi e pregiudizi dei contadini della 
Romagna", Archivio, III (1884), 321-333. On the old crones and "wise women" who may be assembled at the parturition see Z. Zanetti, La medicina, 120, note 1 . 92 C. Simiani, "Usi, leggende e pregiudizi popolari trapanesi", Archivio, X (1891), 488-489; G. Pitrè, op. cit. (see note 86), 18; op. cit. (see note 58), 281. ${ }^{93} \mathrm{Z}$. Zanetti, La medicina, 121 ; cf. G. Finamore, op. cit. (see note 5), 22.

${ }^{94} \mathrm{P}$. H. Williams, op. cit. (see note 4), 88, 94a. For a fuller account cf. Walton Brooks McDaniel, "Some Roman Remedies in Italian Folkmedicine", Trans. and Studies of the College of Physicians of Philadelphia, Ser. 4, vol. XII (1944), 74-76. $95 \mathrm{Z}$. Zanetti, op. cit., 125.

${ }_{96}$ Z. Zanetti, op. cit., 127.

${ }^{97}$ Z. Zanetti, op. cit., 134.

98 We may give a few illustrations of this line of thought out of many available.

The red misura of $\mathrm{S}$. Restituta is used for an attack of measles: G. Pitrè, op. cit. (see note 58), 291. We are told that a red bed-covering or the red mantle of a friar of S. Giuseppe may also help. If a woman in a fever keeps under the bed clothes close to her a red handkerchief during an entire day, it should rid her of it: Z. Zanetti, La medicina, 69. There is also a misura for arthritis: G. Pitrè, op. cit. (see note 46), 269.

${ }^{99}$ E. Canziani, op. cit. (see note 45), 214.

$100 \mathrm{I}$ accept Politian's emendation qui in Verg. Ecl. 4.62 and in Quint. 9.3.8.

101 I. Nieri, op. cit. (see note 58), 356-357. See on this Fanny D. Bergen, Current Superstitions Collected from the Oral Tradition of English-Speaking Folk, 24, no. 42; E. M. Fogel, op. cit. (see note 24), 49, No. 124.

102 Cf. A. F. Chamberlain, The Child and Childhood in Folkthought, 156. On the notion that a moth or a butterfly is a soul cf. Notes and Queries, Ser. 1, III (1850), 220; Ser. 5, VII (1877), 284.

$103 \mathrm{Z}$. Zanetti, La medicina, 140-141.

104 Z. Zanetti, op. cit. $140-141 ; 161$. In a case of rickets, the only thing to do with the donne di fuora who have substituted a changeling is to placate them. G. Pitrè, $o p$. cit. (see note 46), 270-271.

105 Cf., e.g. Lucret. 5.222-227; Plin. N.H. 7.2-3; 11.269. We are told that Vergil did not cry at his birth: Verg. Vita Donatiana (Edit. of Brummer) 2, line 13. According to Pliny, babies begin to speak when they are a year old. It was a portent if one spoke at the age of six months. Those who talk early, walk late: N.H. 11.270. Modern babies are not supposed to smile until the second month, but doting parents may insist that they detect a risus much earlier: cf., e.g., G. Sellew, Pediatric Nursing, 22. See, also, the Scientific Monthly, R. W. Gerard, "The Biological Basis of Imagination", June, 1946, 487. At nine months they reach the "dada" and "mama" stage of speech: cf., e.g., J. Garland, The Youngest of the Family, 26.

106 Even American travelers note the lack of discipline, and, of course, the Germans censure it: cf., e.g., W. Frey, Italia sempiterna, II, 24. On the other hand, Italians themselves note that among the Sicilians the authority of the paterfamilias is strong: Encic. ital., s.v. "Sicilia", 697. P. D. Fischer (Italien und die Italiener $\left.{ }^{2}, 348\right)$ quotes the words of Torquato Tasso: alla virtù latina, o nulla manca o sol la disciplina. The ancients give us a picture of punishment at home and at school that contrasts strongly with anything to be seen now in an upperclass family: cf. O. Kiefer, Sexual Life in Ancient Rome, 68-74. 
107 G. Pitrè, op. cit. (see note 86 ), II, 145: if the baby is not put at once on the floor, it will die in the hospital; G. Finamore, op. cit. (see note 5), 67-68: on piano del focolare; S. A. Guastella, Canti popolari del circondario di Modica, CXIV; cf. A. Dieterich, Mutter Erde ${ }^{3}, 7 ; 10-11$; Non. 528.

$108 \mathrm{We}$ may conjecture this on the basis of Macrob. 1.12.20. H. J. Rose (Primitive Culture, 133) has a different theory: "Laid on ground to provide it with a soul that comes from Mother Earth."

${ }^{109}$ Z. Zanetti, La medicina, 136; Nonne e Bambini, 9.

${ }^{110} \mathrm{C}$. Guerrieri, "Credenze, superstizioni e usi popolari in Rimini e suoi dintorni”, Rivista delle tradizioni popolari italiane, I (1893-1894), 315.

111 Cf., e.g., Jul. Obs. Prod. 37; 48: 41: 44; 46; 47; 83: 51: 66; 88; 111 for these, and, in general, Lucan 1.562-563. Emperor Augustus abhorred freaks of nature (Suet. Aug. 83), but usually the Romans took great interest in such creatures as dwarfs, giants, congenital idiots. The classical student who wishes to find exact parallels for the monstrosities which Roman writers mention as portents may be referred to the illustrations in such books as R. Meyer and E. Schwalbe, Studien zur Pathologie der Entwicklung; E. Schwalbe, Die Morphologie der Missbildungen der Menschen und der Tiere (vol. II); A. Föster, Die Missbildungen des Menschen; F. Ahlfeld, Die Missbildungen des Menschen; Adolph G. Otto, Monstrorum sexcentorum descriptio anatomica; C. J. S. Thompson, The Mystery and Lore of Monsters; Ivar Broman, Normale und Abnorme Entwicklung des Menschen, and especially Barton C. Hirst and George A. Piersol, Human Monstrosities in four volumes.

112 Cic. De Div. 1.43.98; Liv. 27.37.5 ; 39.22 ; Jul. Obs. Prod. 38 ; 46; 81; 86; $92 ; 107 ; 110$. Sometimes the portentous androgynus was not discovered before it had reached some maturity (aged 8,12 or 16 ), but it had to die for the safety of the state: Jul. Obs. Prod. 46; 56; 96; 108; 113.

113 Capit. Ant. Pius 9.1-3. In a more modern spirit Emperor Augustus honored with a monument the grave of a mother who had done so well by the population of her country only to die after her achievement: Gell. 10.2. See also Phlegon Trall. De Mirabilibus, 29.

114 N.H. 7.33. The top record for antiquity seems to have been seven: N.H. 7.33.

115 Cic. De Leg. 3.8.19; Sen. De Ira 1.15.2.

116 The ethical aspects of this are discussed by P. D. Fischer, Italien, 351-352;

C. J. A. Mittermaier, Italienische Zustände, 167-171. See also R. Kleinpaul, Roma Capitale, Römische Lebens- und Landschaftsbilder, $150 \mathrm{ff}$.

117 E. Neville-Rolfe, Naples in 1888, 18-19; cf. A. Rumpelt, Sicilien und die Sicilianer, 161-162.

118 Cf. E. Neville-Rolfe, op. cit. 25.

119 Paul. Exc. 118.6 (Edit. of Lindsay 105.13); cf. Hulsebos, De Educatione et institutione apud Romanos, 28 ; G. Pinto, Storia della medicina in Roma al tempo de' re e della republica, 412 .

120 C. E. Whitcomb, A Little Journey to Italy, 77; Poujoulat, Toscane et Rome, 318-319. The classical student will be reminded of a similar use of a token of hospitality tessera hospitalis. Naturally enough the reclamations are few: Cf. C. R. Weld, Last Winter in Rome, 201; 203. 
121 Some of the most interesting passages are Dion. Hal. 2.15; Plin. Ep. 10.66; Min. Fel. Oct. 31.1-4; Tert. Apol. 9.17-19.

${ }^{122} \mathrm{~K}$. Hooker, Through the Heel of Italy, 202; M. Pasquarelli, op. cit. (see note 4), XV, 327.

123 G. Pitrè, op. cit. (see note 86), 31; P. H. Williams, op. cit. (see note 4), 78; for the Basilicata, M. Pasquarelli, op. cit. (see note 4), XV, 327; for Piedmont, G. Di Giovanni, Usi credenze e pregiudizi del Canavese, 18.

124 Z. Zanetti, La medicina, 108; 126; cf. G. Ferraro, "Botanica popolare di Carpeneto D'Acqui”, Archivio, IV (1885), 188. There are also things to be avoided. A baby should not be allowed to die in its mother's arms if she hopes ever to have any sons born to her: M. Pasquarelli, op. cit. (see note 4), XVI, 55. $125 \mathrm{Z}$. Zanetti, op. cit., 126. Actually, of course, nothing can be done about it: See J. Morris Slemons, The Prospective Mother ${ }^{3}, 45$.

${ }^{126}$ Cf., e.g., S. La Sorsa, Costumi e riti pugliesi, 4; M. Pasquarelli, op. cit. (see note 4), XVI. 53; G. Finamore, op. cit. (see note 5), 60; 62; A. De Nino, op. cit. (see note 66), II, 22-24. A woman who puts her left foot first in climbing stairs may expect to give birth to a girl baby instead of the preferred boy: A. De Nino, op. cit. (see note 66), II, 23. When a baby is born with a fine head of hair, it indicates that the next will be a boy: Z. Zanetti, La medicina, 128: bambino con capelli chiama dietro altri fratelli. Such ideas are, of course, not unusual in other countries: Notes and Queries, Ser. 1, II (1850), 20. For antiquity cf., e.g., N.H. 7.41. It is still a problem for science to solve: cf., e.g., F. C. Irving, The Expectant Mother's Handbook, 187-192; J. M. Slemons, op. cit. (see note 125), 48.

${ }^{127}$ N.H. $25.39-40 ; 26.97 ; 26.162 ; 27.62 ; 27.65 ; 27.125 ; 28.254 ;$ cf. 25.97 for

a different sort of folly.

128 N.H. 28.248; 30.123 ; cf. 28.254 . To insure that a baby's eyes should be black, a pregnant mother ought to eat a shrew-mouse: $N . H .30 .134$.

${ }^{129}$ N.H. 10.154. $\quad{ }^{130}$ Artemid. Oneirocrit. $1.15 ; 3.14$.

131 W. W. Story, Roba di Roma, II, 502; Cf. C. Guerrieri op. cit. (see note $110), 315$. One finds a superstition in various parts of Great Britain to the effect that if at a Christening a girl baby comes first, she will grow up to be bearded, while the boy who has lost his priority at the ceremony will have no hair on his chin: Notes and Queries, Ser. 4, X (1872), 477; Ser. 5, VI (1876), 323; 463; cf. VII (1877), 257; Ser. 7, X (1890), 306; 494. Similar fancy in Sweden: Ser. 7, X (1890), 185.

'132 Herodian 1.5.5.14.

133 See the illustration in Encic. ital. s.v. "Fascia", tav. CXXXIII ; CXXXIV. On the subject: F. M. Guercio, Sicily, 226; Carr, North Italian Folk, 98; D. N. Lees, Tuscan Feasts and Roman Banquets, 39-40; E. A. Reynolds-Ball, Unknown Italy, Piedmont and the Piedmontese, 7.

${ }^{134}$ I have in memory the swathed puttino (but with arms free) of Andrea

Della Robbia that attracts lovers of art to the Loggia dell' Ospedale degl'

Innocenti at Florence.

135 N.H. 7.3 .

${ }^{136}$ N. Hawthorne, Passages from the French and Italian Notebooks, (Riverside Edition) 164. We must remember that he knew nought of pituitary glands. ${ }^{137}$ C. Dickens, Pictures from Italy, 45-46. 
138 W. W. Story, Roba di Roma, II, 508. ${ }^{139}$ An amusing account: H. H. Jackson, Bits of Travel, 199-201. Cf., also, W. D. Howells, Venetian Life, 321. ${ }^{140} \mathrm{E}$. Canziani, op. cit. (see note 45), 214; G. Bacci, op. cit. (see note 78), XV, 48; G. Finamore, op. cit. (see note 5), 68; 72-73; A. Karusio, op. cit. (see note 77), 317; T. W. Lund, The Lake of Como, 65; D. Silvagni, Scene della vita napoletana, 158.

${ }^{141}$ Some believe that if the name of his birthday saint is not included, he will die; M. Pasquarelli, op. cit. (see note 4), XVI, 55. For this belief in England cf. Notes and Queries, Ser. 1, VII (1853), 128.

142 W. W. Story (Roba di Roma, I, 33-34) writes amusingly upon Italian callousness to ridicule that concerns oddities and defects.

143 E. A. Reynolds-Ball, op. cit. (see note 133), 9.

144 The Romans were supposed to keep secret the name of the protecting deity of Rome in order to protect the city against a foe who might summon him to their side. On the subject in general see the admirable discussion of $\mathrm{K}$. F. Smith in his edition of Tibullus, note on 1.2.57-58; Plut. Quaest. Rom. 61; Plin. N.H. 28.18; Macrob. 3.9.3.

145 Suet. Calig. 9; Tac. Ann. 1.41.

146 Tac. Ann. 1.23. ${ }^{147}$ See the famous ancient picture of the wounded Aeneas: Arturo Castiglioni, Storia della Medicina, 205.

148 Cf. N. Borrelli, "Tradizioni e leggende dei colli aurunci", Il folklore italiano, VII (1932), 204; G. Amalfi, Tradizioni ed usi nella penisola sorrentina, 3. The best terse exemplification of such formations known to me is in A. Hoare, An Italian Dictionary, s.v. "Donna" and "Donnona." ${ }^{149} \mathrm{Z}$. Zanetti, La medicina, 134.

150 G. Bacci, op. cit. (see note 78), XV, 52 .

151 M. Pasquarelli, op. cit. (see note 4), XV, 330; XVI, 54.

$152 \mathrm{G}$. Pitrè, Medicina, 202; cf. the use of the mother's own milk for the cure of her infant's crosta lattea, "milk crust": 224.

153 Z. Zanetti, Nonne, 14.

${ }^{154} \mathrm{G}$. Bacci, op. cit. (see note 78), XV, 53.- This reminds me that some

Pennsylvania Germans believed that powwowing would be futile, if the powwower set a price on his sorcery: E. M. Fogel, op. cit. (see note 24), 382.

155 G. Pinoli, "Medicina popolare nel canavese", Archivio, IV (1885), 82.

On such use of ordure medically cf. Walton B. McDaniel, op. cit. (see note 94), 79-80.

156 G. Finamore, op. cit. (see note 5), 69; M. Pasquarelli, op. cit. (see note 4), $\mathrm{XV}, 327$; XVI, 54 .

157 Z. Zanetti, La medicina, 132.

158 Z. Zanetti, op. cit., 145.

159 G. Bacci, op. cit. (see note 78), XV, 53.

160 G. Bacci, op. cit., XIV, 223; L. Marco, "Usi, costumi e credenze popolari di Mottola", Rivista delle tradizioni popolari italiane, I (1893-1894), 298. For an artificial lattaruolo cf. A. De Nino, op. cit. (see note 66), II. 29.

161 P. Mazzuchi, "Leggende, ṕregiudizi e superstizioni del volgo nell' alto polesine", Archivio per l'antropologia e la etnologia, XVIII (1888), 273; W. L. Hildburgh, "Notes on Spanish Amulets", Folklore, XXVI (1915), 409, pl. II, fig. 28 and note 2 . 
$162 \mathrm{Z}$. Zanetti, La medicina, 253. The use of wall-scrapings, floor-sweepings, and the like from Catholic churches for therapeutic purposes is attested for many parts of the world: cf., e.g., E. Canziani, Through the Apennines and the Lands of the Abruzzi, Landscape and Peasant Life, 300; G. Bellucci, op. cit. (see note 38), 60 and fig. 37a; Notes and Queries, Ser. 4, VIII (1871), 505; XII (1873), 385 ; Ser. 6, VI (1882), 6; Ser. 11, VI (1912), 175.

${ }^{163}$ N.H. 37.162. 164 Drinking sow's milk was a more reasonable dependence, N.H. 28.250; taking earthworms in a drink of honied wine defies rationalization: 30.125 .

165 G. Bellucci, Catalogue (see note 45), 64, no. 11 ; L. Eckenstein, "European Amulets", Transactions of the Third Congress for the History of Religions, 79. ${ }^{166}$ Z. Zanetti, Nonne, 13; G. Bellucci, Catalogue, 36, tav. VI, no. 9; 37, tav. VI, no. 19; Amuleti italiani (see note 45) 251: pietra lattea or latteruola.

167 G. Bellucci, Catalogue, 35, tav. VI, no. 2; cf. W. L. Hildburg, op. cit. (see note 161), 66.

168 G. Bellucci, Amuleti italiani, 252; G. B. Corsi, "Sena vetus, superstizioni, canti, indovinelli e giuochi”, Archivio, X (1891), 31. It enjoys favor as a wedding present: T. Nencini, "Un po' di medicina rusticana", Rivista delle tradizioni popolari italiane, I (1893-1894), 888.

169 Z. Zanetti, Nonne, 13.

170 A. De Nino, op. cit. (see note 66), II, 29; Z. Zanetti, La medicina, 145; E. A. W. Budge, Amulets and Superstitions, 319.

${ }^{171}$ M. Pasquarelli, op. cit. (see note 4), XVI, 54; E. Canziani, op. cit. (see note 45), 212. $\quad{ }^{172}$ N.H. 30.131. $\quad{ }^{173}$ N.H. 28.250. $\quad{ }^{174}$ N.H. 28.251.

175 N.H. 30.131.

176 See the commentators on Pers. 3.18; Auson. 12.90-93. Sample cradlesongs to hush-a-bye the baby: I. Rossi, "Ninne-nanne del Casentino", Archivio, XV (1896), 79-81; G. Pitrè, op. cit. (see note 58), 93-96; G. Giannini, Canti popolari toscani, 3-10.

${ }_{177}$ Cf., e.g., Cic. De Orat. 2.39.162 with Aristot. Rhet. 3.4.3 and Sext. Empir. Adv. Rhet. 2.42. See, too, J. Conington, Persius, note on 3.17. The custom was by no means unknown within my lifetime among persons of German ancestry in our country.

178 Colum. R.R. 8.10; cf. Varr. R.R. 3.7.

179 Of course, some of the things that are fed to a child for a purely superstitious reason will, at least, do him little or no harm; e.g., a piece of baked apple to keep him from having diseases of the chest and from having a bad breath when he has grown up: Z. Zanetti, La medicina, 139; cf. Mortimer Menpes, Venice, 207.

180 The Fascist rules for living forbid the use of wine or tobacco before the age of fifteen: F. Fox, Italy of Today, 225. Cf. on wine and other articles of diet, H. F. Brown, Life on the Lagoons, 225-226. 181 Isaiah 7.15. "Butter and honey. Shall he eat that he may know to refuse evil and choose the good" makes it sound doctrine for any Christian land, although the newborn may get sugar instead of honey in these days: cf: Notes and Queries, Ser. 7, I (1886), 145.

182 N.H. 28.257. On medical use of butter on ulcers: N.H. 28.190; Cels. 6.18. 2 C; 6.18.2.1. See also N.H. 11.239. 
${ }^{183}$ For the full story, told with due attention paid to chronology, see W. W. Buckland, A Text Book of Roman Law, 101-141; esp. 103.

184 Cf., e.g., Paul, Exc. 128.8 (Edit. of Lindsay 115.13).

185 It would probably be from Greek nurses that Roman boys and girls would hear of this female spectre: C. T. Ramage, op. cit. (see note 20), 62-63; H. M. Vaughan, The Naples Riviera, 110 ; N. Borreli, op. cit. (see note 148), 170. The Mommo which he thinks may be Momo, the god of ridicule, would more naturally represent Mormo. In any case, I query whether Mammon of Math. 6.24 can be connected in any way with the Italian bugaboo. See, also, G. Perroni, "Mamucca, credenza popolare di Castroreale", Archivio, XX (1901), 537.

${ }^{186}$ Cf., e.g. Lucil. 15.324; Hor. A.P. 340. G. Marchesi, "In Valtellina, costumi, leggende, tradizioni", Archivio, XVII (1898), 419.

187 C. G. Leland, Etruscan Roman Remains, 30.

188 J. Ross, The Land of Manfred, 196; P. Ellero, op. cit. (see note 23), 41-42; G. Gigli, Superstizioni, pregiudizi e tradizioni in Terra d'Otranto con un aggiunta di canti e fiabe popolari, 27-28. As an unbaptized giant: G. Calvia, "Esseri meravigliosi e fantastici nelle credenze sarde e specialmente di Lagudoro", Archivio, XXII (1903), 11. See also B. Frescura, "Folletti e fate, folklore vicentino", Rivista delle tradizioni popolari italiane, I, 611.

$189 \mathrm{O}$. Bruni, La nostra redenzione morale, libro offerto al popolo italiano, 52.

190 C. G. Leland, Etruscan Roman Remains, 241.

191 G. Amalfi, Tradizioni ed usi nella penisola sorrentina, 158; M. Angelini, "La 'Vecchia' dell' Epifania ed i pronostici d'amore di S. Giovanni nel Piceno ed altrove", Archivio, XIII (1894), 21; J. G. Frazer, The Golden Bough, IX, 166-167.

192 I. Nieri, op. cit. (see note 58), 367-371: a list of such terrors.

193 G. Pitrè, op. cit. (see note 58), 201-202; G. Amalfi, op. cit. (see note 191), 156; E. Canziani, Through the Apennines and the Lands of the Abruzzi, Landscape and Peasant Life, 37-39; op. cit. (see note 45), 245; G. Gigli, op. cit. (see note 188), 26; C. Grisanti, "Credenze pregiudizi superstizioni in Isnello", Archivio, XVII (1898), 315-316. Identified with the donne di fuora: Messina e dintorni (see note 23), 79; G. Calvia, op. cit. (see note 188), 10: the Fadas. We call these etymological children of the $F$ ata fairies or fays.

${ }^{194}$ I. Nieri, op. cit. (see note 58), 368-369; cf. G. Pitrè, op. cit. (see note 58), 201-202. It is hard to end the life of the Cumaean Sibyl. Perhaps she will

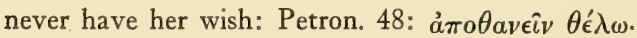

195 E. Canziani, op. cit. (see note 45), 245. Are we to identify her with that Cumaean seeress whose withered form Trimalchio saw caged (Petron. 48.8) and whose bones were finally interred at Cumae (Paus. 10.12.8)?

196 G. Pitrè, op. cit. (see note 58), 196-197; 286.

197 C. Simiani, "Usi, leggende e pregiudizi popolari trapanesi", Archivio, X (1891), 489; "I fatuzzi nella credenza popolare trapanese", Archivio VIII (1889), 337-338. 198 Cf. C. G. Leland, op. cit. (see note 187), 159-160, with, e.g., Plut. Rom. 2.3-4; Plin. N.H. 36.204 .

199 Cf. Gell. 16.17.2 ; August. De Civ. Dei, 4.8; 4.11; 4.21; Non. 108.15 (Edit. of Lindsay, I, 155). 
${ }^{200} \mathrm{G}$. Cocchiara, La vita e l'arte del popolo siciliano nel museo Pitrè, 92.

201 The candidacy of the bat for the identification is ably set forth by S. G. Oliphant, "The Story of the Strix", Transactions of the American Philological Association, XLIV (1913), 133-149; XLV (1914), 49-63.

202 Cf. Ovid, Fast. 6.133-136; 143-148; W. H. Roscher, Lexikon, s.v. "Stringes" and "Striges." See E. Canziani, op. cit. (see note 45), 246.

203 Ovid Fast. 6.101-131; cf. Macrob. Sat. 1.12.31-33.

204 Ovid Fast. 6.141-142; cf. Amor. 1.8.13-14.

${ }^{205}$ N.H. 11.232; cf. Seren. Sammon. Lib. Medicin. 1035-1038.

206 Ovid Fast. 6.143-168.

${ }^{207}$ Petron. 63 ; cf. 134. Cf. L. Villari, On the Roads from Rome, 126; G. B. Corsi, "Sena Vetus, superstizioni, canti, indovinelli e giuochi", Archivio, IX (1890), 521; Zanetti, La medicina, 11.

208 Petron. 63-64.

209 T. Trede, Das Heidentum in der römischen Kirche, IV, 353; Z. Zanetti, La medicina, 11; I. Nieri, op. cit. (see note 58), 371; E. Bonaventura, "Le streghe, credenze popolari pisane", Riv d. trad. pop. ital., I (1893-1894), 932-936.

210 A. De Nino, op. cit. (see note 66), I. 143-145; E. Canziani, op. cit. (see note 45), 246; A. Rini, Popular Superstitions, 84. But, of course, diagnosis is difficult: a toad is supposed to suck not only milk from a cow's udder but blood from a baby: G. Calvia, "Animali e piante nella tradizione popolare sarda e specialmente del Logudoro", Il folklore italiano, I (1925), 200. If a baby is born with livid marks on its body, it may be thought that vampires sucked its blood while still in the womb: Z. Zanetti, La medicina, 130.

${ }^{211}$ A. De Nino, op. cit. I. 168; G. Finamore, op. cit. (see note 5), 57-58: eaten by women during pregnancy. As in the case of wormwood, it should be gathered on Ascension Day: De Maricourt, "Croyances et moeurs à Naples", Archivio, XXII (1905), 547. That is the best time, anyway, to attempt the cure of any sort of obstinate disease: G. Pitrè, Spettacoli e feste popolari siciliane, 257.

212 Z. Zanetti, La medicina, 160.

${ }^{213}$ For ancient Rome there is the notable care with which those of the Flamen Dialis were buried under a fruitful tree: Gell. 10.15.15. Cf. the disposal of the hair-clippings of the Vestal Virgins: Plin. N.H. 16.235; Paul. Exc. 57.17 (Edit. of Linds. 50.12); Apul. Met. 3.16. $\quad 214$ Any part or personal possession will do. Cf. Verg. Ecl. 8.91-93. For modern Italy cf. Z. Zanetti, La medicina, 11; F. Davegno, "Le superstizioni di Portofino", Arch. per l'antropol. XVIII (1888), 90 ; A. Balladoro, "Alcune credenze e superstizioni del popolo veronese", Archivio, XIII (1899), 127; L. D. Gordon, Home Life in Italy, 243; La Marchesa de Villamarina, "Credenze popolari della Valsesia", Riv. d. trad. pop. ital., I (18931894), 134. Fear that a witch may find it accounts for the burning of a milktooth, C. J. S. Thompson, The Hand of Destiny, 24. ${ }^{215}$ G. Pitrè, Medicina, 62; Z. Zanetti, op. cit., 234-235; I. Nieri, op. cit. (see note 58), 375 ; G. Ferraro, "Spigolature popolari monferrine", Archivio, VI (1887), 118; A. De Nino, op. cit. (see note 66), 75; M. Pasquarelli, "Noterelle folkloriche per la basilicata", Riv. di trad. pop. ital., I (1893-1894), 636. See, furthermore, E. M. Fogel, Beliefs and Superstitions of the Pennsylvania Germans, 242, No. 1255 ; 344, No. 1834; Notes and Queries, Ser. 2, I (1856), 386. 
${ }^{216} \mathrm{Cf}$. for a baby's hair, Notes and Queries, Ser. 6, VI (1882), 416. One must burn discarded hair, for if toads find it, and take it into their hole, the careless person will have a perpetual headache: Notes and Queries, Ser. 4, VII (1871), 91. 217 Petron. 104-105. $\quad 218$ N.H. 28.28; Auson. Ecl. $26 . \quad{ }^{219}$ R. M. Cossàr, "Usanze, riti e superstizioni del popolo di Montana nell' Istria", Il folklore italiano, IX (1934), 62; E. Canziani, op. cit. (see note 45), 228; F. Valla, "Medicina e credenze popolari sarde", Archivio, XIV (1895), 43. ${ }^{220} \mathrm{~F}$. Bellizzi, "Credenze e superstizioni pugliesi", Riv. d. trad. pop. ital., I (1893-1894), 459. ${ }^{2211}$ R. M. Cossàr, loc. cit.; cf. Notes and Queries, Ser. 4, I (1868), 575. 222 C. Bottecchia, "Credenze popolari del bellunese", Riv. d. trad. pop. ital., I (1893-1894), 557; G. M. Cossu, "Tradizioni, superstizioni e credenze sarde", Riv. d. trad. pop. ital., I (1893-1894), 222. It is interesting to find this superstition in the United States.: E. M. Fogel, op. cit. (see note 24), 243, No. 1256.

223 F. Valla, loc. cit. 224 E. Canziani, op. cit. (see note 45), 214. But merely washing a baby's palm is said to make it light-fingered: Notes and Queries, Ser. 3, XII (1867), 185. Cf. also C. J. S. Thompson, op. cit., 24-25; F. D. Bergen, Current Superstitions Collected from the Oral Tradition of English-Speaking Folk, 25, no. 55. $\quad 225$ Z. Zanetti, La medicina, 142; Nonne e bambini, 142; G. Pitrè, Medicina, 103; cf. O. Bruni, La nostra redenzione morale, 51: Venetian practice; Notes and Queries, Ser. 5, VIII (1887), 325. The Pennsylvania German superstition prescribes a wait of a year before the first haircut, lest the infant lose its hair, be a weakling, or die young: E. M. Fogel, op. cit. (see note 24), 42, nos. 81-82; 43, no. 83. ${ }^{226}$ E. Canziani; loc. cit. The superstitions have reached England or, perhaps, risen there independently: Notes and Queries, Ser. 1, VI (1852), 312; X (1854), 71; Ser. 2, XII (1861), 500; Ser. 4, VI (1870), 130; 204; 376; Ser. 6, VI (1882), 249; 416; Ser. 9, V (1900), 375; 500; Ser. 9, VI (1900), 93; 173; C. J. S. Thompson, op. cit. (see note 214), 24. ${ }^{227}$ Any strange-looking eye will be particularly open to suspicion. See Walton B. McDaniel, "The Pupula Duplex and Other Tokens of an Evil Eye in the Light of Ophthalmology", Classical Philology, XIII (1918), 335-446.

228 C. T. Ramage, op. cit. (see note 20), 60-61; C. Pigorini-Beri, op. cit. (see note 44), 35; A. Mancarella, "Superstizioni popolari pugliesi", Il folklore italiano, V (1930), 126-151.

${ }^{229}$ Cf., e.g., A. De Nino, op. cit. (see note 66), V, 3; Z. Zanetti, La medicina, 142.

${ }^{230}$ Z. Zanetti, op. cit., 160; M. L. Wagner, "Il malocchio e credenze affini in Sardegna", Lares, II (1913), 133. Spitting away the evil effects of a compliment is, of course, a farflung superstition: cf., e.g., Notes and Queries, Ser. 3, XII (1867), 477.

${ }^{231}$ T. Trede, op. cit. (see note 209), II. 236; M. L. Wagner, op. cit., 133; cf. G. E. Bideri, Usi e costumi del popolo napoletano, 87.

232 S. Salomone-Marino, op. cit. (see note 50), 133.

233 N.H. 28.39.

234 Cat. 5. 11-13.

235 Neither blessings nor property should be counted. As the Tuscan peasant puts it: il suo bene non si numera: A. De Gubernatis, "Psicologia del linguaggio popolare", Rivista delle tradizioni popolari italiane, I, 153: Il contadino 
toscano a significare il gran bene che vuole suol dire che il suo bene non si numera. In Piedmont: Si dice ai proprietari che contano la roba loro per guardarsi dai ladri: roba cuntà 1 lüv la mangia, roba contata se la mangia il lupo. Cf. Notes and Queries, Ser. 5, VIII (1877), 325.

${ }^{236} \mathrm{Z}$. Zanetti, La medicina, 141; J. B. Andrews, "Quelques croyances et usages napoletains", Archivio, XVIII (1899), 45; P. H. Williams, op. cit. (see note 4), 104-105; N. Valletta, Cicalata sul fascino volgarmente detto jettatura con cenni biografici sull autore, 52. For this superstition in North America, cf. Fanny D. Bergen, op. cit. (see note 224) 24, no. 38; 25, no. 52; E. M. Fogel, op. cit. (see note 24 ), 52 , no. 143 .

${ }^{237}$ N.H. 30.138 ; cf. 30.100 .

238 G. Pitrè, op. cit. (see note 46 ), 356.

239 Cf., e.g., Pers. 5.186-188; Dioscor. De Med. Mat. 3.97.

240 N.H. 28.257; cf. 11.166.

${ }^{241}$ N.H. 33.84. We may note the survival of such ideas about gold in North America: Fanny D. Bergen, op. cit. (see note 224), 94, numbers 796-800.

${ }^{242}$ M. D. Martini, "Note folkloristiche presi in Canicatti (Sicilia)", Archivio, $\mathrm{X}(1891), 559$.

${ }^{243}$ For a long list of the protectives in vogue today see A. De Nino, op. cit. (see note 66 ), II, 35.

244 M. Pasquarelli, op. cit. (see note 4), XVI. 56; Z. Zanetti, La medicina, 161: if the witches handle them, they must be replaced by others. The restlessness of the baby indicates that the old ones have been impaired and are not doing their work.

245 G. Pitrè, $o p$. cit. (see note 58), 286; M. Pasquarelli, loc. cit: gives a full statement.

${ }^{246}$ S. La Sorsa, Il folklore nelle scuole di Puglia, 6; G. Amalfi, op. cit. (see note 191$), 4$.

${ }^{247}$ Z. Zanetti, La medicina, 255; M. Pasquarelli, loc. cit. (see note 4).

248 G. B. Corsi, loc. cit. (see note 207); "vita senese", Archivio, IX (1890), 109; cf. Z. Zanetti, La medicina, 160; 255.

249 G. Ferraro, op. cit. (see note 6), 135; 410; M. Pasquarelli, op. cit. (siee note 4), XV, 503; A. De Nino, op. cit. (see note 66), V, 187; Z. Zanetti, La medicina, 155: rue may be put on the belly and on the soles of the feet as well as used internally.

250 S. Salomone-Marino, op. cit. (see note 50), 132; A. De Nino op. cit. V, 186. ${ }^{251}$ The mother may be advised to put a sickle somewhere in baby's bed or cradle: M. Pasquarelli, op. cit., XVI, 56.

${ }^{252}$ A. Dieterich, "A-B-C Denkmäler", Rheinisches Museum, LVI (1901), 104

105; R. S. Conway, Ancient Italy and Modern Religion, 14-15.

${ }^{253}$ Contessa Fulvia Perotti De' Miani, "Credenze e superstizioni di Cassano Murge (Bari)", Rivista delle tradizioni popolari italiane, I (1893-1894), 381.

${ }^{254} \mathrm{~S}$. La Sorsa, op. cit. (see note 246), 6. A broom set against the jamb of the door is a Pennsylvania German way of keeping out the witches: E. M. Fogel, Beliefs and Superstitions of the Pennsylvania Germans, 138, No. 634; cf. 139.

255 In childbirth, death is preferable to the surgeon: Z. Zanetti, La medicina; 120 , note 1 . 
256 G. Amalfi, op. cit. (see note 191), 67; L. De Nardis, Le medichesse del miracolo nella romagna", Il folklore italiano, VIII (1929), 174-177; cf. A. PosseBrázdová, Sardinian Sideshow, 150-151; Z. Zanetti, La medicina, 11. Their secret nostrums for man and beast are passed down as family traditions among the crones of the village: G. Di Giovanni, "Usi, costumi, pratiche, credenze e pregiudizi del novarese", Archivio, V (1886), 447-448. See also P. Riccardi, "Pregiudizi e superstizioni del popolo modenese", Arch. per l'antropol., XX (1890), 333-337.

${ }^{257}$ Cf. M. Pasquarelli, op. cit. (see note 4), 55-56.

${ }^{258}$ Cf., e.g., Z. Zanetti, La medicina, 11; 160-161; 130: on livid marks that are attributed to vampires who have been sucking sustenance from the child while it was still in the womb. See also E. Canziani, op. cit. (see note 45), 246.

${ }^{259} \mathrm{Z}$. Zanetti, La medicina, 130; 150. This accords with Pennsylvania German belief: E. M. Fogel, op. cit. (see note 24), 49, No. 121. But cf. S. La Sorsa op. cit. (see note 246), 4, where a belief is reported that such a Dentatus of today is destined to prosper. On the idea that the phenomenon is something to be dreaded see C. J. S. Thompson, The Hand of Destiny, 23. The average age for the first appearance of teeth, regularly the two lower central incisors, is six months. It is unusual enough for even these two to be in at birth, but there may be even more, e.g., eight. Sometimes they are extracted to enable the mother to nurse. See G. Sellew, Pedriatic Nursing, 23; and, in general, on Dentio Praecox C. G. Grulee and B. E. Bonar, The Newborn, III, 130; E. L. Stone, The Newborn Infant, A Manual of Obstetrical Pediatrics, 235; J. Garland, The Youngest of the Family, 23.

260 N.H. 7. 68-69. On the phenomenal record of the latter cf. Gell. 2.11.

261 One of the portents noted in the De Prodigiis of Julius Obsequens, 66.

262 A comprehensive account of orris-root: A. H. Murray, Sketches on the Old Road through France to Florence, 280-285; cf. also E. Strasburger, Rambles on the Riviera (a translation by O. and B. C. Casey of Streifzüge an der Riviera), 307.

${ }^{263}$ For a long list of the objects that he may mumble see A. De Nino, op. cit. (see note 66), II, 35 .

${ }^{264}$ N. H. 28.258; Seren. Sammon, Lib. Medicin. 1031-1032.

265 N.H. 30.136; cf. $30.24 \quad 266$ N.H. 30.137. It is also used in a recipe for an intestinal procidence. $\quad 267$ N.H. 30.138. 268 N.H. 30.139.

269 N.H. 28.257. For an English survival: Notes and Queries, Ser. 2, VIIJ (1859), $326 . \quad 270$ N.H. 32.137.

${ }^{271} \mathrm{Z}$. Zanetti, La medicina, 150. A hyacinth (red zircon) may be used: Nonne e bambini, 25. I can find, however, no ancient parallel for that modern superstition that teething the upper teeth first prognosticates nearness of death, because they suggest by their appearance the mattocks that are used in the excavation of a grave: S. La Sorsa, op. cit. (see note 78), 58-59.

$272 \mathrm{Z}$. Zanetti, La medicina, 150 . It is advisable also to bathe them with some of the blood which spurts out when a cock's comb is cut off: Z. Zanetti, Nonne $e$ bambini, 24-25. The use of the brains of a hare for a fretful baby is not confined to Italy: cf. Notes and Queries, Ser. 6, I (1880), 34.

273 N.H. 28.259; 30.135; cf. 30.139; Seren. Sammon. Lib. Medicin. 1033-1034. ${ }^{274}$ Z. Zanetti, La medicina, 151; 254. 
275 Z. Zanetti, Nonne e bambini, 25.

${ }^{276} \mathrm{G}$. Bellucci, op. cit. (see note 38), 47; M. L. Wagner, op. cit. (see note 230), 140, tav. II; Z. Zanetti, La medicina, 254; O. Keller, Die antike Tierwelt, II, 541-544; fig. 155-156.

277 G. Bellucci, op. cit. (see note 38), 38, fig. 18; 39, fig. 19; 40, fig. 20; cf. the pectunculus: 41, fig. 21; Amuleti (see note 45), 253, numbers 14-16.

278 E. P. Heaton, By-paths in Sicily, 83. We may compare the conca venerea used against worms and the purcidduzzu di $S$. Antoni shell: G. Pitrè, op. cit. (see note 46), 397; 457: a cowrie amulet for nephritic colic.

279 Cf. Z. Zanetti, La medicina, 8. See also my article "Undesirable Guests and Unwilling Hosts, Parasites in Ancient and Modern Italian Folkmedicine", Transactions and Studies of the College of Physicians of Philadelphia, XV (1947), 26-35.

280 Cat. De Agric. 126; cf. Cels. 4.24.1, and, for modern times, C. CoronediBerti, op. cit. (see note 6), 9. To kill tapeworms our doctors may prescribe the fresh bark of pomegranate root macerated in hot water and boiled down to half bulk. The doses are followed by a purgative: E. Cautley, The Diseases of Infants and Children, 313. But the preferred remedy is the liquid extract of male fern (filis mas), the oleoresin of aspidium: H. R. Litchfield, Therapeutics of Infancy and Childhood, 1893; H. Koplik, The Diseases of Infancy and Childhood, 558; Sir James F. Goodhart, The Diseases of Children, ${ }^{12}$ 155; H. Kleinschmidt, Treatment of Disease in Infants and Children (Translation of H. M. Greenwald), 143.

281 Pliny's list of expellants includes lupines, rue, pepper, ordinary wormwood and sea wormwood: N.H. 22.155; 27.48; 27.53; 32.100. Cf. Cels. 4.24.7. For Italian use: Z. Zanetti, Nonne e bambini, 33; C. Coronedi-Berti, op. cit., 8; M. Pasquarelli, op. cit. (see note 4), XV, 503. The roundworm is assailed with wormwood, i.e. santonin from santonica (Artemisia paucifora) and calomel: J. P. Crozier Griffith, The Diseases of Infants and Children, ${ }^{3}$ 647; H. D. Chapin, Diseases of Infants and Children, 203; Dawson Williams, Medical Diseases of Infancy and Childhood, ${ }^{2} 403$, or with the safer and more effective oil of chenopodium: L. Fischer, The Baby and Growing Child, 145; E. Cautley, op. cit. (see note 280), 314; H. Kleinschmidt, op. cit. (see note 280), 145. Wormwood is also used as a remedy for the Oxyuris vermicularis, pin worm, seat worm, or thread worm: L. Fischer, op. cit., 144; D. Williams, op. cit., 405; Eustace Smith, On the Wasting Diseases of Infants and Children, ${ }^{6} 240$.

282 For antiquity: Cels. 4.24.1-2. The pediatrician may use an infusion of garlic in an enema to dislodge pin worms: H. M. McClanahan, Pediatrics for the General Practitioner, 209; E. Cautley, op. cit. (see note 280), 315.

${ }_{283}$ M. Pasquarelli, loc. cit.; Zanetti, La medicina, 155; C. Coronedi-Berti, op. cit., 9. Among ancient references: Cels. 4.24.1.

284 Zanetti, La medicina, 157; Nonne e bambini, 33 ; M. Pasquarelli, op. cit., 503; G. Ferraro, op. cit. (see note 6), 133.

285 N.H. 22.155.

286 G. Pinoli, op. cit. (see note 155), 79-80. Rue is an Italian cure-all: A. D’Amato, "Folklore irpino", Il folklore italiano, I (1925), 83.

287 G. Pitrè, op. cit. (see note 46), 388. 
288 Z. Zanetti, La medicina, 155.

${ }^{289} \mathrm{M}$. Pasquarelli, op. cit. (see note 4), XV, 503. The less agreeable method: G. Di Giovanni, op. cit. (see note 256), 71. For the least rueful way to administer it to the young see C. Coronedi-Berti, op. cit. (see note 6), 8-9.

${ }^{290} \mathrm{Z}$. Zanetti, La medicina, 156 and note 1.

291 Z. Zanetti, La medicina, op. cit., 157. The Pennsylvania German may put pulverized glass there, in the belief, I suppose, that it is the external point nearest to the worms: E. M. Fogel, op. cit. (see note 24), 269, no. 1395.

292 G. Pitrè, op. cit. (see note 46), 397.

${ }^{293}$ Z. Zanetti, La medicina, 254; G. Bellucci, Catalogue (see note 45), tab. VII; cf. G. Palumbo, "Credenze e superstizioni salentine", Rivista delle tradizioni popolari italiane, I (1893-1894), 618; S. Seligmann, op. cit. (see note 46), 205.

${ }^{294} Z$. Zanetti, loc. cit. (corno di serpente); 258; G. Bellucci, Catalogue (see note 45), 60, no. 27; P. Saintyves, "Talismans et reliques tombés du ciel", Revue des études ethnographiques et sociologiques, II, 183.

295 N.H. 37.164.

296 G. Bellucci, Catalogue (see note 45), 60, no. 27.

${ }^{297}$ Z. Zanetti, La medicina, 155 ; S. Raccuglia, "Medicina popolare siciliana", Rivista delle tradizioni popolari italiane, I (1893-1894), 727.

298 P. H. Williams, op. cit. (see note 4), 168.

${ }^{299}$ Z. Zanetti, La medicina, 156; Nonne e bambini, 33. Cf. T. J. Pettigrew, On Superstition Connected with the History and Practice of Medicine and Surgery, 104.

${ }^{300}$ M. Pasquarelli, op. cit. (see note 4), XV, 503. Another chief cause of the infestation is eating cheese, loc. cit.

${ }^{301}$ E. Canziani, op. cit. (see note 45), 214.

302 Encic. ital., s.v. "Animale", 369. A little saliva spat into its mouth by somebody who has known its great-grandfather or great-grandmother is supposed to help: G. M. Cossu, "Tradizioni, superstizioni e credenze sarde", Rivista delle tradizioni popolari italiane, I (1893-1894), 222. Italy has, of course, no monopoly of such fantastic notions. In Cheshire the frog cure is advised for whooping-cough: C. J. S. Thompson, The Hand of Destiny, 153. The Yorkshire child whose sore throat has been cured by the live frog held in its mouth by the legs can thereafter cure any other case of it by merely blowing into the sufferer's mouth: Notes and Queries, Ser. 4, IX (1872), 401; cf. Ser. 1, V (1852), 393; Ser. 2, IX (1866), 319; Ser. 7, XI (1891), 470; Ser. 12, VII (1920), 246. In Devonshire we learn that the victim of thrush should inhale the cold breath of a duck from its open bill inserted in his mouth, op. cit., Ser. 1, VIII (1853); cf. Ser. 9, XII (1903), 47. An alternative term for thrush is frog, and a somewhat similar disease called thrush attacks the frog or frush of a horse's hoof. Let those who are interested in the influence of words on folkmedicine ponder these. As for the disease itself, which is credited to a fungus, the reader may consult E. L. Stone, The Newborn Infant, 233; Sir James F. Goodhart, op. cit. (see note 280), 199-200. The term is often applied loosely to any sore mouth: D. Williams, op. cit. (see note 281), 294.

${ }^{303}$ A. De Nino, op. cit. (see note 66), II, 31. Inserting a fish in the mouth as a cure of whooping-cough has been reported from Philadelphia: Notes and 
Queries, Ser. 5, III (1875), 345-346; cf. W. G. Black, Folkmedicine, 36-37. Replaced alive in the river, it gives the disease to the other fish, as is shown by their coming to the surface to cough: Notes and Queries, Ser. 5, IX (1878), 64-65. A Pennsylvania German prescription to stop an infant from slobbering is to pass a small fish through its mouth and then return it alive to the water: E. M. Fogel, op. cit. (see note 24), 269, no. 1399; one to cure a child's whoopingcough is to put a live trout into its mouth while fasting and then return it to the stream: op. cit. 270 , No. 1399; 329, No. 1805. For use of a fish in dentition: 314, No. 1672.

304 Z. Zanetti, Nonne e bambini, 27 ; A. De Nino, op. cit., V, 128.

305 C. Grisanti, Usi, credenze, proverbi e raconti popolari d' Isnello, 144; J. B. Andrews, op. cit. (see note 236), 42. Kissing a negro is supposed to cure a Pennsylvania German baby of whooping-cough, E. M. Fogel, op. cit. (see note 24), 337, no. 1791. It is not done in our Southern states.

${ }^{306}$ N.H. 28.66; cf. $28.91 ; 28.163 ; 28.244$.

307 G. Finamore, op. cit. (see note 5), 67; 69. The old Roman and the modern Italian prescriptions make us wonder at the possible connections with them of the similar Pennsylvania beliefs and practices: E. M. Fogel, op. cit. (see note 24), 38, No. 50. ${ }^{308}$ Z. Zanetti, op. cit. (see note 304), 16; La medicina, 139. Let the dermatologist who has no faith in this at least remember how old such ideas are: cf. Plin. N.H. 28.109; 28.185.

${ }^{309}$ G. Amalfi, op. cit. (see note 191), 61; A. Balladoro, "Alcune credenze e superstizioni del popolo veronese”, Archivio, XVIII (1899), 125; M. Pasquarelli, op. cit. (see note 4), XVI, 52 ; G. B. Corsi, op. cit. (see note 207), X, 31; J. B. Andrews, "Quelques croyances et usages napoletains", Archivio, XVIII (1899), 41. For a highly amusing account of its administration: A. De Nino, op. cit. (see note 66), V, 173-174. Why mice, boiled or roasted, are a prescription of English folkmedicine not only for bedwetting but also for whooping-cough and measles, is a question I must leave with my readers. Cf., e.g., for the first use: Notes and Queries, Ser. 1, II (1851), 435 ; VI (1852), 311; for the second: Ser. 1, I (1850), 397; II (1850), 197; 510; Ser. 2, VIII (1865), 145; 4, II (1868), 220; III (1869), 216; for the third: Ser. 1, I (1850), 430. The prescription among the Pennsylvania Germans for incontinence of urine is fried mouse or mouse pie: E. M. Fogel, Beliefs and Superstitions of the Pennsylvania Germans, 281, No. 1480 and 1483. An alternative is to eat a little sausage made of the pudendum of a pig: 282, No. 1482. These obnoxious diets might have to last a long time, since enuresis is hard to cure. Punishment avails little: G. Sellew, op. cit. (see note 259), 399; H. R. Litchfield, op. cit. (see note 280), 1767-1769. ${ }^{310}$ N.H. 30.138. On the numerous remedies derived from mice: G. B. Dawson, Healing, Pagan and Christian, 105-106. Instead of eating mice, a child could have roasted hippocamps or take certain other fish in his food: N.H. 32.109, or the bladder of a hyaena, so prepared as to be drunk in wine: N.H. 28.103.

311 M. Pasquarelli, op. cit. (see note 4), XVI, 54; A. De Nino, op. cit. (see note 66), II 25-26; cf. 75; G. Finamore, op. cit. (see note 5), 67; 122; G. Pitrè, op. cit. (see note 86 ), 24 .

312 N.H. 30.42-43; 30.61; 30.64; cf. Marcell. De Medicamentis 27.33; 27.123; 29.35 . 
313 G. Pitrè, op. cit. (see note 46 ), 369.

314 M. Pasquarelli, op. cit. (see note 4), XV, 502. An incantation of six verses helps: 502-503. If a horse, ass, or cow has a similar pain, one must get a girl who is a twin to give the part affected three good kicks: F. Valla, "Medicina e credenze popolari sarde", Archivio, XIV (1895), 45-46.

$315 \mathrm{Z}$. Zanetti, Nonne $e$ bambini, 15. Even kissing a baby too frequently is said to cause them. They have always been common enough in infancy to keep mothers guessing about the cause: cf. D. Williams op. cit. (see note 281), 451.

${ }^{316}$ E. Canziani, op. cit. (see note 162), 8; Z. Zanetti, La medicina, 153; G. Bastanzi, "Superstizioni religiose nelle provincie di Treviso e di Belluno", Archivio per l'antropologia e la etnologia, XVII (1887), 272; G. Bellucci, op. cit. (see note 38), 104-105; 107; fig. 57; cf. G. Ferraro, "Toccaferro", Archivio, XX (1901), 414; L. Di Pasquale, loc. cit. (see note 58). Some epileptics wear at their neck le chiavette di S. Domenico all the time: Encic. ital. s.v. "Umbria."

317 G. M. Cossu, "Tradizioni, superstizioni e credenze sarde", Rivista delle tradizioni popolari italiane, I (1893-1894), 222; Z. Zanetti, La medicina, 254; Nonne e bambini, 25-26.

318 Z. Zanetti, La medicina, 153; 254.

319 Z. Zanetti, Nonne e bambini, 17.

320 E. Canziani, op. cit. (see note 162), 7 ; Z. Zanetti, La medicina, 255; Nonne e bambini, 21.

${ }^{321}$ Z. Zanetti, La medicina, 153.

322 Z. Zanetti, Nonne e bambini, 30; cf. La medicina, 91; 252.

323 N.H. 28.259.

324 N.H. 28.258.

325 N.H. 28.257. $\quad{ }^{326}$ N.H. 32.137.

${ }^{327} \mathrm{Z}$. Zanetti, La medicina, 154. For the administration of the brains of a hare as a soporific in England: Notes and Queries, Ser. 6, IV (1881), 406; 457; sometimes the brains of a calf: 458 . On the unpredictable attacks of screaming that afflict even healthy babies the layman may be referred, e.g., to Sir James F. Goodhart, op. cit. (see note 280), 728-729; J. P. C. Griffith, op. cit. (see note 281), 887-888; L. Fischer op. cit. (see note 281), 147; E. Smith, op. cit. (see note 281 ), 210-211.

328 J. B. Andrews, op. cit. (see note 236), 42.

329 C. Coronedi-Berti, op. cit. (see note 6), 6-7.

330 E. Canziani, $a p$. cit. (see note 45 ), 214.

${ }^{331}$ N.H. 22.59. $\quad 332$ N.H. 30.135. $\quad{ }^{333}$ N.H. 32.138. $\quad 334$ N.H. 30.136.

335 N.H. 30.137. $\quad{ }^{336}$ N.H. 30.139. $\quad 337$ N.H. 28.258. $\quad 338$ N.H. 28.259.

The reference is probably to ulcerative stomatitis: cf. H. M. McClanahan, op. cit. (see note 282), 147; J. P. C. Griffith, op. cit. (see note 281), $520 . \quad{ }^{339}$ N.H. 28.257.

${ }^{340}$ M. Vezzani, Usanze, tradizioni e leggende dell' Apennino Reggiano, 13; G. Finamore, op. cit. (see note 5), 78. E. Canziani, op. cit. (see note 45), 214. On the same principle, if menstrual cloths are put in the wash above and not underneath the garments of men, the men will suffer atrocious pains: Z. Zanetti, La medicina, 101; 97: beating the cloths will communicate menstrual suffering; cf. 99. 
341 G. Ferraro, op. cit. (see note 6), 188; cf. I. Nieri, op. cit. (see note 58), 373. 342 P. H. Williams, op. cit. (see note 4), 13; 144; A. De Nino, op. cit. (see note 66$),$ I, 144; G. Pitrè, "Alberi e piante negli usi e nelle credenze popolari siciliane", Archivio, V (1886), 180; J. B. Andrews, "Neapolitan Witchcraft", Folklore, VIII (1897), 1; F. Davegno, "Le superstizioni di Portofino", Archivio per l'antropologia e la etnologia, XVIII (1888), 88. On la notte di S. Simone: M. Placucci, op. cit. (see note 91), IV, 48; cf. Messina e dintorni (see note 23), 79.

${ }^{343}$ On his place in medicine: M. Neuburger, Geschichte der Medizin, I, 292.

344 Cat. De Agric. 160 ; Plin. N.H. 17.267.

345 The practice is astonishingly widely attested: M. Pasquarelli, op. cit. (see note 4), XV, 503-504; A. Karusio, "Pregiudizi popolari putignanesi (Bari)", Archivio per l'antropologia e la etnologia, XVII (1887), 315-316; A D'Amato, "Folklore irpino", Il folklore italiano, I; (1925), 88, no. 17; E. P. Heaton, By-paths in Sicily, 90-100; 110; R. Corso, Reviviscenze, studi di tradizioni popolari italiane, 7; 36; 44; M. L. Wagner, Sopra alcune pratiche magiche, 402. Similar superstition is reported from England: E. Sidney Hartland, "Cleft Ashes for Infantile Hernia", Folklore, VII (1896), 303-306, plates II and III. Also from our country and Germany, Notes and Queries, Ser. 6, I (1880), 16; 75 ; 234. Cf., also, C. S. Burne, The Handbook of Folklore, 156; W. G. Black, Folkmedicine, 67-68; C. J. S. Thompson, The Hand of Destiny, 26. There is an interesting, though not quite convincing, theory that the perforated stone or the cleft of a tree through which an afflicted child is passed represents the female genitalia, so that the act symbolizes a new birth for the victim, a regeneration to health, shall we say? See Benjamin L. Gordon, The Romance of Medicine, 489-490. A fact which greatly helps probably in fostering faith in the cure is that umbilical hernia (a case pictured by John A. Foote, Diseases of the New Born, 148, fig. 51) and inguinal hernia (see same book, 150, fig. 53) and hydrocele, which ignorant persons can readily confuse with the latter, all have more or less tendency to a spontaneous cure. The layman may be referred to William Sheldon, Diseases of Infancy and Childhood, 224-225; E. Feer, The Diagnosis of Children's Diseases, 389; C. G. Grulee and B. E. Bonar, op. cit. (see note 259), III, 158; 160; 263; L. E. Holt, The Diseases of Infancy and Childhood, ${ }^{6}$ 113; 636; Henry E. Tuley, The Diseases of Children, 494; Henri de Rothschild, Traité d'hygiène et de pathologie du nourrisson et des enfants du premier age, 514; John Ruhräh, A Manual of the Diseases of Infants and Children, 67.

346 N.H. 30.135. 347 N.H. 30.137. $\quad 348$ N.H. 30.136.

349 Cf. Z. Zanetti, Nonne e bambini, 34.

350 One of the most recent authoritative works on Italy, Christ Stopped at Eboli, by Carlo Levi, which deals with Lucania, can be cordially recommended to those who have no knowledge of how primitive the life of South Italians can be. 








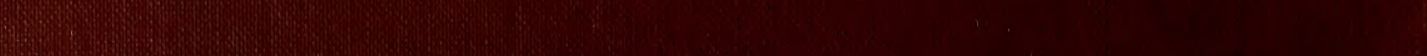

